

\section{Sumário}

I. Dossiê Especial: History of International Law ...................................1

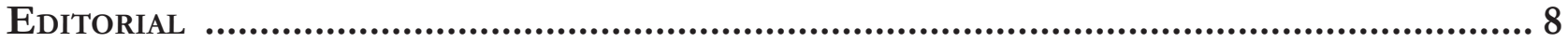

What does it mean to apply history in international law studies? ....................................................... 8

Arthur Roberto Capella Giannattasio

SuR LA NATURE DU Droit ISLAMIQUe............................................................................14

Hocine Benkheira

Islamic Shari’a Law, History and Modernity: Some Reflections .................................25 Suleiman A. Mourad

The (Un)practical Secularization Process: International Law and Religion as So-

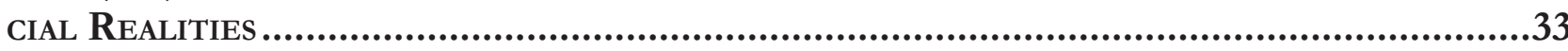

Douglas de Castro

BRAZILIAN LITERATURE ON INTERNATIONAL LAW DURING THE EMPIRE REGIME. OR THE DIFFUSION OF INTERNATIONAL LAW IN THE PERIPHERIES THROUGH APPROPRIATION AND ADAPTATION.

Airton Ribeiro da Silva Júnior

Natural, POSitivo, romano E Universal? INVESTigaÇão SObre O Direito das GENTES EM

Tomás de Aquino

Rafael Zelesco Barretto

II. Artigos sobre outros temas

VINCULAÇÃO DOS DIREITOS ECONÔMICOS, SOCIAIS E CULTURAIS: UMA DISCUSSÃO DO DESENVOLVImento humano com base no conceito de Amartya Sen sobre o mínimo existencial.....99

Natalia Mascarenhas Simões Bentes e Yasmim Salgado Santa Brígida

A NOVA LeI de MigraÇão E A PROTEÇão CONFERIDA AO APÁtrida: ALINHAMENTO BRASILEIRO AO PADRÃO INTERNACIONAL DE DIREITOS HUMANOS

Pedro Henrique de Faria Barbosa e Sylvio Loreto

E se o Supremo Tribunal Federal (STF) restabelecer a vigência da Convenção n. 158 
da Organização Internacional do Trabalho (OIT) na ordem Jurídica brasileira? SoBRE UMA POSSÍVEL REVIRAVOLTA, PELA VIA DO DIREITO INTERNACIONAL, DAS LEIS TRABALHISTAS BRASILEIRAS 138

Daniel Damasio Borges

JULGADOS DA CORTE INTERAMERICANA SOBRE CASOS BRASILEIROS E POLÍTICAS PÚBLICAS: REFLEXÕES ACERCA DE POSSÍVEIS INFLUIÇÕES 165

Rafael Osvaldo Machado Moura

CREATING BRIDGES BETWEEN INTERNATIONAL RELATIONS THEORY AND INTERNATIONAL HUMAN RIGHTS LAW: CONSTRUCTIVISM AND THE ROLE OF BRAZIL IN THE INTER-AMERICAN SYSTEM OF HUMAN RIGHTS 179

Ismael Francisco de Souza, Luciana Rocha Leme e Erick da Luz Scherf

Justiça de transição na Argentina e o Sistema Interamericano de Direitos Humanos: uMa ANÁlise do CASo Luis Muiña (“REgRa 2x1”) 199

Emilio Peluso Neder Meyer e Jessica Holl

A legalidade e legitimidade da INTERVEnÇão humanitÁria: UMA MEDIDA AINDA NECESSÁRIa.219 Natália Caye Batalha Boeira

O Acordo de Escazú E o ACESSo À INFORMaÇão AMbiental no Brasil. 252 Érica Bezerra Queiroz Ribeiro e Bruno Amaral Machado

Dos POVOS NATIVOS AO SURGIMENTO DOS MOVIMENTOS SOCIAIS: INFLUÊNCIAS DOS DISCURSOS JURÍDICOS, RELIGIOSOS E MÉDICOS PARA A CONSTRUÇÃO DO CONCEITO DE HOMOSSEXUALIDADE NO BRASIL .267 Bruno Rafael Silva Nogueira Barbosa e Robson Antão de Medeiros

Aspectos Jurídicos da PARTicipaÇão dA UNião Europeia NA OMC: COMPREENDENdo SUTILEZAS DE UM DELICADO ENLACE. 291

Camilla Capucio

Path to judicial activism? The use of "Relevant rules of international law" by the WTO Appellate Body

Mariana Clara de Andrade

LEVEZA E PESO NA MEDIAÇÃO COMERCIAL INTERNACIONAL: O CONTEÚDO JURÍDICO DO ACORDO CORPORATIVO MEDIADO E SUA INCORPORAÇÃo PELO DiREITO BRASILEIRO .324 Henrique Lenon Farias Guedes 
JURISDIÇÃO INTERNACIONAL E AS DIFICULDADES DE EXECUÇÃO DE SENTENÇAS INTERNACIONAIS NO BRASIL

Nevitton Vieira Souza

O DEVER DE COOPERAÇÃo NOS CONTRATOS DE VENDA INTERNACIONAL DE MERCADORIAS: PRESSUPOSTOS TEÓRICOS E REPERCUSSÕES PRÁTICAS DA CLÁUSULA GERAL DA BOA-FÉ OBJETIVA PARA A APLICAÇÃo DA CISG .358

Angelo Gamba Prata de Carvalho

A DiMENSÃo JURÍdiCA DO IMPERIALISMO NA (DES)ORDEM GLOBAL CAPITALISTA: UMA ANÁLISE COM BASE NA CRÍTICA MARXISTA AO DIREITO INTERNACIONAL E ÀS RELAÇÕES POLÍTICO-ECONÔMICAS DE DOMINAÇÃO E DEPENDÊNCIA.

Thomaz Delgado De David, Maria Beatriz Oliveira da Silva e Rosane Beatris Mariano da Rocha Barcellos Terra

A participaÇão de Brasil e Estados Unidos na formulação das regras multilaterais do

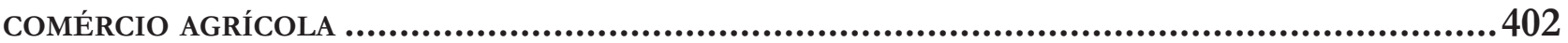

Vera Thorstensen, Vivian Daniele Rocha Gabriel e Alebe Linhares Mesquita

A galáxia lex e a construÇão de um Sistema jurídico transnacional ........................ 441

Eugênia Cristina Nilsen Ribeiro Barza e Jéssyka Maria Nunes Galvão

Has the Ability of Truth Commissions to Recommend Amnesty Been Effective in Enhancing Perpetrator Cooperation? 453 Jeremy Sarkin

A CONCEPTUAL PAPER ON THE POLICY-FRAMEWORK THAT MIRRORS THE DYNAMIC LINK BETWEEN Human Security, Social Protection and Safety Nets, and Food and Nutritional Security: The Case of the "Gulayan sa Paaralan Program", the Philippines.... 478 Renato Lagapa Base

INCENTIVISING SMALLHOLDER FARMER LIVELIHOODS AND CONSTRUCTING FOOD SECURITY THROUGH HOME-GROWN SCHOOL FEEDING: EVIDENCE FROM NORTHERN GHANA .491

Clement Mensah

Policy COHERENCE In THE IMPLEMENTATION OF THE 2030 AgENDA FOR SUSTAINABLE DEVELOpment: the Brazilian School Feeding Programme Case Study .506 Mariana Werlang Girardi 


\title{
Justiça de transição na Argentina e o Sistema Interamericano de Direitos Humanos: uma análise do Caso Luis Muiña ("regra 2x1")*
}

\author{
Transitional justice in Argentina and the \\ Inter-American System of Human Rights: an \\ analyses of the Case Luis Muiña ("rule $2 \times 1$ ")
}

\author{
Emilio Peluso Neder Meyer** \\ Jessica Holl***
}

\section{Resumo}

Em 2017, a Suprema Corte de Justiça da Nação Argentina publicou a decisão referente ao caso Luis Muiña, que havia sido condenado pela prática de crimes contra a humanidade durante a ditadura argentina e pleiteava a aplicação da chamada "regra 2x1". Essa regra consiste em um benefício processual que assegura a contagem em dobro do período em que o detido fica em prisão cautelar, a partir do momento em que fossem completados dois anos de prisão. A Suprema Corte decidiu, em apertada maioria, pela aplicação do benefício. Contudo, nove dias após a publicação da decisão, foi aprovada pelo Congresso Nacional a Lei n. 27.362, que impede a aplicação da regra nos casos de crimes contra a humanidade. A partir desses fatos, o presente artigo tem como objetivo demonstrar que benefícios processuais, em casos de crimes contra a humanidade, ferem entendimentos consolidados da Corte Interamericana de Direitos Humanos e da Comissão Interamericana de Direitos Humanos. A hipótese de que há maior consolidação da proteção regional de direitos humanos na Argentina em vista da reação legislativa oferecida pelo Congresso Nacional. Metodologicamente, são apresentados os principais aspectos do caso Luis Muiña; na sequência, é traçado um panorama sobre o entendimento dos órgãos interamericanos sobre os crimes aqui referidos; e, por fim, é trabalhada a importância de override e backlash no caso, para a efetivação dos direitos humanos. O método dedutivo serviu-se de uma análise documental das decisões e recomendações domésticos e regionais envolvidos. Os resultados da pesquisa indicam que, em havendo instituições domésticas previamente subordinadas ao Sistema Interamericano de Direitos Humanos, tentativas de excepcionar proteções existentes podem ser barradas em outras instituições, ainda mais se houver pressão popular.

Palavras-chave: Sistema Interamericano de Direitos Humanos. Argentina. Crimes contra a humanidade. Regra " $2 \times 1$ ".

\footnotetext{
*** Mestranda em Direito pelo Programa de Pós-Graduação em Direito da UFMG com bolsa CNPQ. Professora Substituta da Universidade Federal de Ouro Preto. Pesquisadora do Centro de Estudos sobre Justiça de Transição da UFMG. E-mail: jessica_holl@ymail.com.

** Professor Adjunto de Direito Constitucional da Faculdade de Direito da UFMG (Graduação e Pós-Graduação, Mestrado e Doutorado). Mestre e Doutor em Direito pela UFMG. Coordenador do Centro de Estudos
sobre Justiça de Transição da UFMG. Visiting Researcher no King's College Brazil Institute (2014-2015). Pesquisador residente no Instituto de Estudos Avançados Transdisciplinares da UFMG (2018-2019).E-mail: emiliopeluso@ gmail.com.
} 


\section{Abstract}

In 2017, the Supreme Court of Justice of the $\mathrm{Na}$ tion of Argentina published the decision regarding the Luis Muiña case, who was charged for the commitment of crimes against humanity during the Argentinian dictatorship and pledged the application of the so called " $2 \mathrm{x} 1$ rule". This rule consists on a processual benefit which assured the counting in double of the period the prisoner remained of pretrial detention, since it was completed two years of detention. The Supreme Court decided, with a narrow majority, for the applicability of such benefit. However, nine days after the decision was published, it was approved by the National Congress the Statute Law n. 27.362, which prevents the application of the " $2 \mathrm{x} 1$ rule" in cases of crimes against humanity. Based on these facts, the present article has as its aim to demonstrate that processual benefits, in the case of crimes against humanity, breach consolidated comprehensions of the Inter-American Court of Human Rights and the Inter-American Commission of Human Rights. The hypothesis is that there is a major consolidation of the protection of human rights in Argentina due to the legislative reaction offered by National Congress. Main aspects of Luis Muiña case are presented; an outlook of inter-american organs comprehension on the crimes here discussed is presented; finally, we debate the importance of override and backlash for human rights effectiveness. Deductive method used a documental analyses of the domestic and regional decisions and recommendations that were involved. The results of the research indicate that, if there are domestic institutions previously subordinated to the Inter-American System of Human Rights, attempts to except the existent protections can be avoided in other institutions, especially if one adds popular pressure.

Keywords: Inter-American System on Human Rights. Argentina. Crimes against humanity.

\section{INTRODUÇão}

Em termos regionais, a Argentina tem se destacado por cumprir uma agenda de justiça de transição que é, ao mesmo tempo, compromissada com os órgãos do Sistema Interamericano de Direitos Humanos e voltada a um forte acento da responsabilização criminal.
Esse cenário destoa do Brasil em que, apesar das mais de trinta ações penais ajuizadas pelo Ministério Público Federal, o Poder Judiciário permanece fiel à decisão do Supremo Tribunal Federal na ADPF 153, que julgou válida a interpretação de que crimes praticados por agentes da ditadura estavam abarcados pela Lei 6.683/1979 (Lei de Anistia), ignorando-se as condenações em casos como Gomes Lund e Herzog. ${ }^{1}$

O objetivo deste trabalho é o de verificar como determinados benefícios processuais podem estar em desacordo com entendimentos firmados no âmbito do Sistema Interamericano de Direitos Humanos. Por se tratar de crimes contra a humanidade, a aplicação da chamada "regra 2x1" aos acusados da prática de delitos nas ditaduras argentinas viola a forma como a Comissão Interamericana e a Corte Interamericana de Direitos Humanos, de modo sólido, demandam a punição doméstica de graves violações de direitos humanos.

A hipótese é a de que, na Argentina, já há uma forte adesão ao Sistema Interamericano de Direitos Humanos, algo que define positivamente seu sistema jurídico doméstico. Ao tempo em que a Suprema Corte de Justiça da Nação Argentina contrapõe-se a um entendimento por ela mesma incorporado do sistema regional, ela gera uma reação construtiva na sociedade e nos movimentos sociais argentinos capaz de recuperar os propósitos de combate e enfrentamento de crimes de contra a humanidade, sedimentando uma concepção de justiça de transição claramente preocupada com a responsabilização criminal.

A metodologia utilizada recorre a uma análise vertical de uma decisão da Suprema Corte da Nação Argentina que foi rapidamente respondida com uma reação legislativa fortemente apoiada por movimentos sociais. Em uma perspectiva crítica, será resgatado o processo de reação à decisão tomada pela Suprema Corte de Justiça da Nação Argentina no caso Luis Muiña, reação esta que contou com a aprovação da Lei 27.362/2017. A decisão procurou estender os benefícios de execução da pena dados pela Lei 24.390/1994 (a chamada "regra

1 MEYER, Emilio Peluso Neder. Criminal responsibility in Brazilian transitional justice: a constitutional interpretative process under the paradigm of International Human Rights Law. Indonesian Journal of International and Comparative Law, v. IV, p. 41-72, 2017. Para uma outra análise da decisão, PUGLIESE, Yuri. Lei brasileira da anistia: os conflitos entre o acordo social e a cooperação internacional. Revista de Direito Internacional, Brasília, v. 9, n. 2, p. 93-113, jul./dez. 2012. 
$2 \times 1$ ") àqueles condenados pela prática de crimes contra a humanidade. Apresentaremos, inicialmente, os principais argumentos trazidos pelos Ministros da Corte no referido caso, apontando o contexto político e social em que a decisão foi tomada, assim como a rápida mobilização social com consequente resposta legislativa.

Abordaremos como o Sistema Interamericano de Direitos Humanos trata os crimes contra a humanidade imputados a Muiña como crimes contra a humanidade, percorrendo a jurisprudência sobre privação arbitrária da liberdade, tortura e desaparecimento forçado. Isto permitirá comprovar a ideia de que a aplicação da chamada "regra $2 \times 1$ " ao referido caso ignora e relativiza uma disciplina normativa especial dos crimes contra humanidade de alcance necessário para Sistema Interamericano de Direitos Humanos. Ao cabo, demonstraremos como o necessário override legislativo se justificou ante um efetivo e rápido backlash de movimentos sociais contra a decisão judicial. Tais reações legislativas comprovam que a consolidação doméstica de decisões e recomendações do Sistema Interamericano de Direitos Humanos na Argentina permitem que outras instituições possam reagir ante a tentativa do Poder Judiciário de oferecer uma menor proteção contra os crimes contra a humanidade.

\section{2. $O$ CAso LuIs MuIÑa}

Em 2017, a Suprema Corte de Justiça da Nação Argentina foi questionada quanto à aplicabilidade de um benefício processual na contagem da pena de Luis Muiña, condenado pela prática de crimes contra a humanidade durante a ditadura argentina. A decisão final da Suprema Corte reconheceu a aplicabilidade do benefício, em respeito aos princípios da aplicação da pena mais favorável e da razoável duração do processo, ambos estabelecidos na Constituição argentina e em instrumentos internacionais que compõem o bloco constitucional em vigor no país. Contudo, nove dias após a publicação da decisão da Suprema Corte, foi publicada nova lei interpretativa, determinando que o benefício processual em questão não é aplicável para os casos de crimes contra a humanidade. Para uma melhor compreensão dos aspectos envolvidos nessa discussão na Argentina e seus reflexos na discussão da justiça de transição em toda a América Latina, inicialmente, uma análise mais aprofundada dos fatos ocorridos mostra-se necessária.

Luis Muiña foi condenado pelo Tribunal Oral Criminal Federal n. 2 (TOF n. 2) da Argentina a uma pena de treze anos de privação da liberdade pela prática de crimes contra a humanidade, conforme o disposto nos artigos $2^{\circ}, 40,41,45,54,55,144$ inciso $1^{\circ}$ e último parágrafo, em função do art. 142 inciso $1^{\circ}$ — texto segundo a lei n. 20.642 - e art. 144 parágrafo $1^{\circ}$ — texto segundo a lei n. 14.616 - do Código Penal argentino. Muiña foi considerado coautor do crime de privação ilegal da liberdade, cometido por funcionário público em abuso de suas funções e sem o cumprimento dos requisitos legais, agravado pela prática de tortura em virtude das condições de encarceramento e do tratamento dispensado às vítimas e do crime de desaparecimento forçado, ${ }^{2}$ visto que uma das vítimas possui seu paradeiro desconhecido. ${ }^{3}$ A sentença também determinou a contagem da pena de 13 anos de acordo com o art. $7^{\circ}$ da Lei n. 24.390/1994, em consonância com o disposto no art. $2^{\circ}$ do Código Penal, que determina a aplicação da pena mais benéfica ao acusado. ${ }^{4}$ Assim, após dois anos de prisão preventiva, seriam computados dois dias de prisão preventiva por cada dia efetivamente cumprido (dispositivo mais conhecido como a "regra do 2x1").

Em face dessa sentença, foi interposto recurso de cassação (recurso de casación), pelo Ministério Público Fiscal, que considerou a versão original da Lei n. 24.390/1994 inaplicável ao caso. A Sala IV da Câmara Federal de Cassação Penal anulou o cômputo punitivo do TOF n. 2, de acordo com o solicitado pelo Ministério Público. Como salientado pelo Min. Horacio Rosatti, relator do caso na Suprema Corte, a Sala IV da Câmara Federal afirmou que:

$[\ldots]$ uma sociedade não pode castigar mais
severamente um fato ocorrido no passado que
o mesmo fato ocorrido no presente, posto que
as normas refletem a valoração social da conduta
para uma comunidade e esse é um limite do
poder punitivo do Estado. Isto é: temos o direito
constitucional à aplicação da lei penal mais benigna
retroativamente em virtude de que o disposto na lei
mais benigna reflete a mudança na valoração que a
comunidade efetua a respeito da conduta imputada.
Não obstante, a norma que previa a aplicação

2 ARGENTINA. Ministério Público Fiscal. CSJ 1574/2014/ RH1. Relator: Min. Horacio Rosatti. 3 de maio de 2017. p.25.

3 ARGENTINA. Ministério Público Fiscal. CSJ 1574/2014/ RH1. Relator: Min. Horacio Rosatti. 3 de maio de 2017. p. 5-7.

4 ARGENTINA. Ministério Público Fiscal. CSJ 1574/2014/ RH1. Relator: Min. Horacio Rosatti. 3 de maio de 2017. p.1. 
do '2x1' não foi a expressão de uma mudança na valorização social da classe de delitos que foram atribuídos neste processo, sendo que apenas se adotou, durante um curto período de tempo, um mecanismo dirigido a diminuir o prazo das prisões preventivas.

Por isso, ela não é o tipo de norma para a qual se destina o direito de aplicação da lei penal mais benigna ${ }^{5}$.

Restando afastada a aplicação da "regra 2x1" pela Câmara Federal de Cassação Penal, a defesa interpôs recurso extraordinário federal, declarado inadmissível, e, em sequência, suscitou uma questão de queixa federal. Esta teve sua admissibilidade apreciada em conjunto com o mérito pela Suprema Corte, uma vez que a determinação do alcance do art. $2^{\circ}$ do Código Penal pleiteada mostrava-se indissociável da alegada arbitrariedade da decisão recorrida (e que tornaria o recurso de queixa à Suprema Corte admissível) ${ }^{6}$.

Conforme a decisão da Suprema Corte disponibilizada em seu endereço eletrônico na internet, ${ }^{7}$ o relator, Min. Horacio Rosatti, apresentou voto pela aplicação da "regra do 2x1" ao caso Luis Muiña, no que foi seguido pelos Ministros Carlos Fernando Rosenkrantz e Elena I. Highton de Nolasco, tendo o Min. Presidente Ricardo Luis Lorenzetti e o Min. Juan Carlos Maqueda apresentado votos dissidentes. ${ }^{8}$ Essa divisão dos ministros da Suprema Corte, já indica, por si só, o quão controversa é a matéria, por envolver a redução da pena aplicada a condenados por crimes contra a humanidade em

5 ARGENTINA. Ministério Público Fiscal. CSJ 1574/2014/ RH1. Relator: Min. Horacio Rosatti. 3 de maio de 2017. p. 30-31.

6 ARGENTINA. Ministério Público Fiscal. CSJ 1574/2014/ RH1. Relator: Min. Horacio Rosatti. 3 de maio de 2017. p. 3.

7 ARGENTINA. Ministério Público Fiscal. CSJ 1574/2014/ RH1. Relator: Min. Horacio Rosatti. 3 de maio de 2017. pDisponível em: <http://sjconsulta.csjn.gov.ar/sjconsulta/documentos/ verDocumentoByIdLinksJSP.html?idDocumento $=7373073$, acesso 20/6/2017>.

8 É curioso que Rosenkrantz e Rosatti foram nomeados pelo Presidente Maurizio Macri por meio de decreto, recorrendo ele a o que dispõe o art. 99, n. 19, da Constituição argentina. Ocorre que dois nomes já haviam sido indicados por sua antecessora, Cristina Kirchner, que optou pelos juízes Eugenio Sarrabayrouse e Domingo Sesin; entretanto, a aprovação do Senado específica para o cargo (de maior de dois terços) não havia ocorrido antes do final de seu mandato - é o procedimento previsto especificamente pelo art. 99, n. 4, da Constituição. Posteriormente, o Senado faria a aprovação dos nomes indicados por Macri em procedimento de duvidosa (no mínimo) inconstitucionalidade. PERTOT, Werner. Macri se decidió por la Corte de manga. p.1. Disponível em: <https://www.pagina12.com. ar/diario/elpais/1-288291-2015-12-15.html>. Acesso em: 20 jun. 2017. um dos países latino-americanos que promoveram, de forma mais eficaz, a persecução de agentes da ditadura responsáveis por graves violações de direitos humanos.

$\mathrm{Na}$ decisão final, a Suprema Corte destacou que, de acordo com o art. $2^{\circ}$ do Código Penal argentino, se a pena vigente no momento do cometimento do crime for diferente da lei em vigor no momento em que a decisão sobre o caso for proferida ou se for diferente de alguma lei existente no ponto intermediário desses dois eventos - fato ilícito e proferimento da sentença aplicar-se-á a lei mais benéfica. E, de acordo com sua jurisprudência, as regras atinentes ao cômputo da prisão preventiva são de caráter material, o que implica a aplicação do referido princípio da lei penal mais benéfica. ${ }^{9}$ Ademais, indicou que a primeira fonte de interpretação de um dispositivo legal é sua própria letra e que os termos empregados pelo legislador foram conscientemente escolhidos. Por esses motivos, afastou o argumento apresentado pelo Ministério Público Fiscal e adotado pela IV Sala da Câmara Federal de Cassação Penal de que a aplicação da pena mais benéfica só ocorreria quando esta representasse uma mudança da valoração social. Ressaltou, ainda, que, em um Estado Democrático de Direito, as mudanças nas valorações sociais são expressas exatamente por mudanças legislativas, como a do caso em tela, que representou uma mudança da valoração social da prisão preventiva. ${ }^{10}$

A Suprema Corte considerou, também, que a não aplicação da "regra 2x1" representa uma violação do princípio da legalidade, uma vez que nenhum instrumento normativo apresenta qualquer condicionante à aplicação do princípio da norma mais benéfica. E que, em contrapartida, o art. $2^{\circ}$ do Código Penal é expresso ao utilizar o advérbio "sempre" indicando a universalidade da aplicação desse princípio. Dessa forma, em respeito ao princípio da legalidade, não caberia à Corte criar qualquer exceção não prevista pelo legislador, por se tratar de matéria penal.

Em seguida, a Suprema Corte destaca que está fora de questionamento o caráter continuado do crime de desaparecimento forçado cometido pelo recorrente, conforme o art. $3^{\circ}$ da Convenção Interamericana sobre Desaparecimento Forçado de Pessoas de 1994, que

9 ARGENTINA. Ministério Público Fiscal. CSJ 1574/2014/ RH1. Relator: Min. Horacio Rosatti. 3 de maio de 2017. p. 4.

10 ARGENTINA. Ministério Público Fiscal. CSJ 1574/2014/ RH1. Relator: Min. Horacio Rosatti. 3 de maio de 2017. p. 4-5. 
possui hierarquia constitucional na Argentina e a já reiterada jurisprudência do Tribunal. Entretanto, essa qualificação não é suficiente para afastar a aplicação da lei mais benéfica, uma vez que não há previsão no Código Penal - nem em qualquer outra legislação — de um tratamento diferenciado para os casos de cometimento de crimes permanentes. ${ }^{11}$

Assim, ainda que existam dúvidas quanto à aplicabilidade do princípio da lei mais favorável para os crimes dessa natureza, deve-se adotar a interpretação mais benéfica ao réu, no caso, ao recorrente, uma vez que se trata de matéria penal. Do princípio da legalidade resulta a exigência de se adotar a interpretação mais restritiva, considerado o limite semântico do texto em disputa, posto que o Direito Penal se caracteriza como a última alternativa a ser empregada no ordenamento jurídico. ${ }^{12}$

Na sequência, a Suprema Corte destaca que, no presente caso, ela deveria pronunciar-se acerca de uma matéria sobre a qual ainda não havia uma jurisprudência consolidada. Nesse ponto, são enumerados casos que indicam que o Tribunal já se pronunciou em situações que envolviam o desaparecimento forçado e crimes permanentes de forma geral, assim como em casos que requerem a aplicação da norma penal mais benéfica, mas nunca em casos que envolvessem as duas questões simultaneamente. Desse ponto, parte para a análise de jurisprudência internacional, não sendo capaz, também, de identificar casos que envolvam simultaneamente a discussão sobre a aplicação da lei penal mais benéfica e o cometimento de crimes permanentes. É feita menção a casos da Corte Interamericana de Direitos Humanos (CorteIDH) que envolvem crimes permanentes e a possibilidade de imputação de um crime que não era tipificado pela legislação interna do Estado quando do seu cometimento (Gelman vs. Uruguay, 2011 e Tiu Tojín vs. Guatemala, 2008), mas, em nenhum deles, são apresentadas considerações sobre a aplicação de uma lei penal mais benéfica ${ }^{13}$. E, no caso Argüelles e outros vs. Argentina, também da CorteIDH, não foi discutida a própria "regra 2x1" da Lei n. 24.390/1994, mas a necessidade de que houvesse um prazo máximo de duração

11 ARGENTINA. Ministério Público Fiscal. CSJ 1574/2014/ RH1. Relator: Min. Horacio Rosatti. 3 de maio de 2017. p. 6-7.

12 ARGENTINA. Ministério Público Fiscal. CSJ 1574/2014/ RH1. Relator: Min. Horacio Rosatti. 3 de maio de 2017. p. 8.

13 ARGENTINA. Ministério Público Fiscal. CSJ 1574/2014/

RH1. Relator: Min. Horacio Rosatti. 3 de maio de 2017. p. 10. das prisões preventivas. ${ }^{14}$

A Suprema Corte considera, ainda, que o art. $7^{\circ}$ da Lei n. 24.390/1994 esteve vigente em um período intermediário entre o cometimento do crime e a prolação da sentença, de modo que o art. $2^{\circ}$ do Código Penal de fato impõe a sua aplicação, como lei mais benéfica ao réu. $\mathrm{E}$ o fato de o réu ter sido condenado pelo cometimento de crimes contra a humanidade não permite, por si só, o afastamento do disposto no art. $2^{\circ}$ do Código Penal, uma vez que não há qualquer previsão nesse sentido, nem mesmo quando se considera a jurisprudência de tribunais internacionais. Nesse ponto, destaca que:

\begin{abstract}
Mais ainda, a melhor resposta que uma sociedade respeitosa da lei pode dar ao cometimento de crimes de lesa humanidade e a única maneira efetiva e de acordo com princípios de não se parecer com aquilo que se combate e se reprova é o estrito cumprimento das leis e dos princípios que caracterizam o Estado de Direito, o que neste caso requer decidir com absoluto apego ao que está claramente ordenado pelo art. $2^{\circ}$ do Código Penal, em razão do disposto pelo art. 18 da Constituição Nacional e pelos arts. $9^{\circ}$ da Convenção Americana de Direitos Humanos e 15.1 do Pacto Internacional de Direitos Civis e Políticos, convenções internacionais que contam ambas com hierarquia constitucional [na Argentina] por assim dispor o art. 75 inciso 22 da Constituição Nacional. ${ }^{15}$
\end{abstract}

Em seguida, ressalta que o princípio da lei penal mais benéfica está presente até mesmo no Estatuto de Roma, que regula o funcionamento do Tribunal Penal Internacional, responsável pelo julgamento de crimes como genocídio, crimes de guerra e crimes contra a humanidade. ${ }^{16}$ Bem como ressalta que outros tribunais internacionais responsáveis pelo julgamento de genocídios, como o Tribunal Penal Internacional para a antiga Iugoslávia, reconheceram o caráter imperativo do princípio da aplicação da norma penal mais benéfica.

Merece, ainda, destaque trecho do voto do relator, Min. Horacio Rosatti, que afirma:

A humanidade contra a qual foram cometidos estes crimes exige do Estado de Direito a necessária imparcialidade na aplicação das leis referidas a seu julgamento, pois do contrário correr-se-ia o risco de percorrer o mesmo caminho de declive moral que se transitou no passado.

14 ARGENTINA. Ministério Público Fiscal. CSJ 1574/2014/ RH1. Relator: Min. Horacio Rosatti. 3 de maio de 2017. p. 11.

15 ARGENTINA. Ministério Público Fiscal. CSJ 1574/2014/ RH1. Relator: Min. Horacio Rosatti. 3 de maio de 2017. p. 12. 16 ARGENTINA. Ministério Público Fiscal. CSJ 1574/2014/ RH1. Relator: Min. Horacio Rosatti. 3 de maio de 2017. p. 12-13. 
Que, finalmente, de acordo com o expressado, cabe manifestar que a existência de obrigações internacionais assumidas pelo Estado Argentino para garantir a investigação, o julgamento e a sanção aos crimes de lesa humanidade e às graves violações perpetradas aos direitos humanos, cuja rigorosa observância não se olvida de juízo, deve ser cumprida pelos tribunais argentinos sem infringir os princípios constitucionais de legalidade e devido processo, cujo descumprimento também podem acarretar responsabilidade internacional ${ }^{17}$.

Dessa forma, a Suprema Corte de Justiça, por maioria de três ministros e com dois votos dissidentes (do Presidente Juiz Ricardo Luis Lorenzetti e do Juiz Juan Carlos Maqueda), reconheceu admissível o recurso interposto e determinou a suspensão dos efeitos da sentença apelada, isto é, determinou que fosse mantida a decisão de primeira instância, de modo a aplicar a "regra do 2x1" ao caso Luis Muiña. A decisão é passível de inúmeras críticas que acompanhariam a reação dos movimentos sociais. Por ora, podemos lembrar que a aplicação da lei penal mais favorável ignora a dimensão do delito cometido - um crime contra a humanidade é equiparado a crime comum.

Com isso, abriu as portas para mais de 300 repressores dos 700 em prisão, segundo as declarações de Jorge Auat, promotor dos crimes contra humanidade do Ministério Público. Na prática, seria uma espécie de uma anistia para os repressores — um indulto ou comutação da pena encoberta - e um retrocesso enorme para o processo de justiça transicional argentino e regional. ${ }^{18}$

Assim, a aplicação do benefício processual equivaleria a uma modalidade de anistia, o que, como veremos, é rechaçado por provimentos do Sistema Interamericano de Direitos Humanos já aceitos pelo sistema judicial argentino. De uma perspectiva crítica, cuida-se de verdadeiro retrocesso.

A resposta dada ao caso Luis Muiña pela Suprema Corte de Justiça não correspondeu às expectativas dos grupos da sociedade civil argentina que, historicamente, se mobilizaram pela persecução penal dos agentes envolvidos nas violações de direitos humanos ocorridas durante o período de ditadura militar. Conforme noticiado pelo Jornal The New York Times, por meio das

17 ARGENTINA. Ministério Público Fiscal. CSJ 1574/2014/ RH1. Relator: Min. Horacio Rosatti. 3 de maio de 2017. p. 24.

18 ROLDAN, Andres del Rio. A Corte Suprema e a falidade sentença do 2x1. Jota , p. 1. Disponível em: <https://www.jota.info/ opiniao-e-analise/artigos/a-corte-suprema-e-a-falida-sentenca-do2x1-15082017>. Acesso em: 14 nov.2018. redes sociais a sociedade civil argentina mobilizou-se de modo a organizar manifestações no dia 10 de maio de 2017 na Praça de Maio, em Buenos Aires, e em outras cidades do mundo, como na Cidade do México. O lema dessas manifestações foi "Ni olvido ni perdón. No al 2x1. Nunca más genocidas libres." (Nem esquecimento nem perdão. Não ao $2 \times 1$. Nunca mais genocidas livres.). Esses atos foram convocados por organismos de direitos humanos ligados à causa da memória e verdade na Argentina (Abuelas de Plaza de Mayo; Madres de Plaza de Mayo Linea Fundadora; H.I.J.O.S Capital; Asamblea Permanente por los Derechos Humanos - APDH; Asociación Buena Memoria; Comisión Memoria, Verdad y Justicia Zona Norte; Familiaresy Compañeros de los 12 de la Santa Cruz; Fundación Memoria Histórica y Social Argentina; Liga Argentina por los Derechos del Hombre; Movimento Ecuménico por los Humanos - MEDH ${ }^{19}$ e ganharam significativa repercussão internacional. O próprio presidente Macri, em uma conferência de imprensa em Mendoza, também no dia 10 de maio, afirmou ser contrário a toda ferramenta que facilite a impunidade. ${ }^{20}$

Mesmo antes dos atos públicos contra a aplicação da "regra 2x1", iniciou-se no Congresso Nacional Argentino uma mobilização para a aprovação de uma lei interpretativa que vedasse a aplicação do referido benefício processual nos casos de crimes de genocídio e de crimes permanentes. No dia 9 de maio — menos de uma semana depois da publicação da sentença pela Corte Suprema de Justiça no caso Luis Muiña, que ocorreu no dia 3 de maio - a Câmara dos Deputados aprovou o texto inicial da lei. Essa votação foi marcada pela formação de uma rara coalizão entre o grupo dominante e a oposição, de forma que o texto foi aprovado com 212 votos favoráveis e apenas 1 contrário (do deputado Alfredo Olmedo), e também pela presença das Madres y Abuelas de Plaza de Mayo. Já no dia 10 de maio, o texto enviado pela Câmara dos Deputados foi aprovado sem modificações pelo Senado, com 56 votos favoráveis. Assim, já no dia 12 de maio de 2017, foi publicado no Diário Oficial a Lei n. 27.362/2017, que determina, em seu art. $1^{\circ}$, a não aplicação da "regra $2 \times 1$ " para as

19 POLITI, Daniel. Argentines Fight Court's Leniency for Human Rights Crimes. The New York. Times, p.1. Disponível em: $<$ https://www.nytimes.com/2017/05/13/world/americas/argentinamauricio-macri-luis-muia.html>. Acesso em: 20 jun. 2017.

20 EL GOBIERNO promulgó la ley para limitar la aplicación del 2x1 a represores y genocidas. Parlamentario, p.1. Disponível em: $<$ http://www.parlamentario.com/noticia-101020.html>. Acesso em: 20 jun. 2017. 
categorias de crimes de lesa humanidade, genocídio ou crimes de guerra, de acordo com o direito interno e internacional. ${ }^{21}$

Portanto, observou-se a ocorrência do fenômeno de legislative override, que ocasionou a superação da decisão proferida pela Suprema Corte de Justiça no caso Luis Muiña, a partir da promulgação, de forma quase imediata, da Lei n. 27.362/2017. ${ }^{22}$ Ademais, é interessante observar como durante todo o desenvolvimento do caso foram levantadas questões concernentes à necessidade de se respeitar o Direito Internacional dos Direitos Humanos, em especial, os entendimentos veiculados no Sistema Interamericano de Direitos Humanos.

Dessa forma, na sequência será analisado o entendimento da Comissão Interamericana de Direitos Humanos (CIDH) e da Corte Interamericana com relação aos principais elementos envolvidos no caso, isto é, os crimes pelos quais Luis Muiña foi condenado (detenção arbitrária, prática de tortura e desaparecimento forçado) e a aplicação da "regra 2x1".

\section{Perspectivas a partir do Sistema Interamericano de Direitos Humanos}

A Comissão Interamericana de Direitos Humanos e a Corte Interamericana de Direitos Humanos constituem-se em órgãos ligados à Organização dos Estados Americanos (OEA) destinados a assegurar a proteção dos direitos humanos na região. As denúncias de violações de direitos humanos em face de algum dos Estados-membros da OEA e que se sujeitam à jurisdição da Comissão e da Corte Interamericana, são apresentadas perante a CIDH, que realiza um julgamento prévio de admissibilidade da petição. Quando do julgamento do mérito da denúncia, a Comissão pode, como uma das

21 Lei n. 27.362/2017 - Art. $1^{\circ}$ Em conformidade com o previsto na lei 27.156 , no artigo $7^{\circ}$ da lei 24.390 - derrogada pela lei 25.430 - não é aplicável a condutas delitivas que se enquadrem na categoria de crimes de lesa humanidade, genocídio ou crime de guerra, segundo o direito interno ou internacional. (Tradução livre para o português do original: Ley 27362 - Artículo $1^{\circ}$ - De conformidad con lo previsto en la ley 27.156, el artículo $7^{\circ}$ de la ley 24.390 - derogada por ley 25.430 - no es aplicable a conductas delictivas que encuadren en la categoría de delitos de lesa bumanidad, genocidio o crímenes de guerra, según el derecho interno o internacional.)

22 STEPHANOPOULOS, Nicholas. The Case for the Legislative Override. UCLA Journal of International Law and Foreign Affairs 250, p. 251-295, 2005. medidas cabíveis, determinar a remessa do caso para Corte, que processará e julgará a conduta do Estado. Dessa forma, ambas as instituições desenvolveram em conjunto entendimentos sobre as matérias de direitos humanos, no que estão inclusos os crimes de lesa humanidade imputados a Luis Muiña, isto é, privação arbitrária de liberdade, tortura e desaparecimento forçado. Dessa forma, parte-se para uma análise do entendimento do Sistema Interamericano de Direitos Humanos acerca do cometimento desses crimes e da possibilidade de aplicação do benefício processual da "regra 2x1" no caso em tela.

\subsection{Privação arbitrária de liberdade}

No que se refere à privação arbitrária de liberdade, tanto a CorteIDH como a CIDH reconhecem que ela implica, necessariamente, uma violação ao direito à integridade e à dignidade humana. Nesse sentido, no caso Loayza Tamayo vs. Peru (1997), a Corte Interamericana destacou que "Todo uso da força que não seja estritamente necessário por causa do próprio comportamento da pessoa detida constitui um atentado à dignidade humana", 23 o que pode ser aplicado, diretamente, ao caso Luis Muiña, quando da detenção arbitrária das cinco vítimas. Ademais, é reconhecido um caráter inderrogável ao direito à integridade, que não pode ser suspenso em nenhuma hipótese pelos Estados. ${ }^{24}$

Também é reconhecida a responsabilidade do Estado pela observância do direito à integridade de todo indivíduo que esteja sob sua custódia, uma vez que é o Estado o responsável pelo pleno cumprimento dos direitos previstos na Convenção Americana ${ }^{25}$ e no Direito Internacional dos Direitos Humanos como um todo. Nesse sentido, além da privação arbitrária da liberda-

23 Tradução livre para o Português do original: "Todo uso de la fuerza que no sea estrictamente necesario por el propio comportamiento de la persona detenida constituye un atentado a la dignidad humana." (CORTE INTERAMERICANA DE DERECHOS HUMANOS. Cuadernillo de Jurisprudencia de la Corte Interamericana de Derechos Humanos $n^{\circ}$ 10: integridad personal. p.5. Disponível em: $<$ http://www.corteidh.or.cr/sitios/libros/todos/docs/integridad10.pdf>. Acesso em: 30 jun. 2017.).

24 Entendimento consagrado no caso do Massacre do Povo Bello vs. Colómbia, de 2006 (ibid., p. 12).

25 CORTE INTERAMERICANA DE DERECHOS HUMANOS. Cuadernillo de Jurisprudencia de la Corte Interamericana de Derechos Humanos $n^{\circ}$ 9: personas privadas de liberdad. p.63. Disponível em: <http://www.corteidh.or.cr/sitios/libros/todos/docs/privados9.pdf>. Acesso em: 30 jun. 2017. 
de já consistir em uma ofensa aos direitos das vítimas, as condições a que elas foram submetidas também ensejam a responsabilidade estatal. $\mathrm{E}$ isso não apenas no caso de exposição à tortura física e psicológica (como será trabalhado adiante), mas também no que se refere à exposição da vítima a condições desumanas e degradantes. Note-se que a submissão a condições desumanas e degradantes daqueles que estão sob custódia estatal gera a responsabilidade do Estado independente de se tratar de privação arbitrária de liberdade ou não. Conforme apresentado no caso Neira Alegría e outros vs. Peru, julgado em 1995:

[...] toda persona privada de libertad tiene derecho a vivir en condiciones de detención compatibles con su dignidad personal y el Estado debe garantizarle el derecho a la vida y a la integridad personal. En consecuencia, el Estado, como responsable de los establecimientos de detención, es el garante de estos derechos de los detenidos. ${ }^{26}$

Essa especial responsabilidade do Estado por aqueles que se encontram sob sua custódia deve-se à relação de sujeição que se estabelece entre a pessoa privada de liberdade e o Estado, uma vez que, como destacado no caso "Instituto de Reeducação do Menor" vs. Paraguai (2004), ${ }^{27}$ o Estado pode regular aspectos essenciais da vida do indivíduo em razão das condições próprias do encarceramento.

Portanto, é responsabilidade do Estado proteger aqueles que estejam sob sua jurisdição, especialmente aqueles que se encontram detidos em algum órgão estatal, assegurando o respeito às liberdades e garantias internacionalmente consagradas e seu pleno exercício por todos os indivíduos. ${ }^{28}$ Assim, ao mesmo tempo em que o estado tem o direito e o dever de garantir manutenção da segurança e da ordem pública, também possui

26 CORTE INTERAMERICANA DE DERECHOS HUMANOS. Cuadernillo de Jurisprudencia de la Corte Interamericana de Derechos Humanos $n^{\circ}$ 9: personas privadas de liberdad. p.5. Disponível em: $<$ http://www.corteidh.or.cr/sitios/libros/todos/docs/privados9. pdf>. Acesso em: 30 jun. 2017.

27 CORTE INTERAMERICANA DE DERECHOS HUMANOS. Cuadernillo de Jurisprudencia de la Corte Interamericana de Derechos Humanos $n^{\circ}$ 9: personas privadas de liberdad. p.7. Disponível em: $<$ http://www.corteidh.or.cr/sitios/libros/todos/docs/privados9. pdf $>$. Acesso em: 30 jun. 2017.

28 Entendimento explicitado pela CorteIDH no caso do Cárcere do Urso Branco, envolvendo o Brasil (2002) (CORTE INTERAMERICANA DE DERECHOS HUMANOS. Cuadernillo de Jurisprudencia de la Corte Interamericana de Derechos Humanos $n^{\circ}$ 9: personas privadas de liberdad. p.6. Disponível em: <http://www.corteidh. or.cr/sitios/libros/todos/docs/privados9.pdf>. Acesso em: 30 jun. 2017.). a obrigação de respeitar os procedimentos legalmente previstos e de atuar em conformidade com os direitos humanos, com destaque para a necessidade de respeitar o direito à vida. ${ }^{29}$

Ademais, a CorteIDH e a CIDH reconhecem que as pessoas privadas ilegalmente de sua liberdade encontram-se em uma situação de particular vulnerabilidade, uma vez que estão submetidas a um risco certo de que outros direitos seus sejam violados, como o direito à integridade física e o direito de serem tratadas dignamen$\mathrm{te}^{30}$. Daí surgiria uma responsabilidade ainda maior do Estado investigar os fatos ocorridos e promover a responsabilização dos envolvidos, de modo a não permitir a impunidade e a perpetuação da prática da privação arbitrária da liberdade por parte dos agentes estatais.

\subsection{Tortura}

Para chegar na atual definição dos elementos constitutivos da prática de tortura, a Corte e a Comissão Interamericana de Direitos Humanos basearam-se na Convenção Americana, em sua jurisprudência e nos entendimentos desenvolvidos por outros órgãos de proteção aos direitos humanos. ${ }^{31}$ Dessa forma, reconhece-se como "torturas físicas e psíquicas aqueles atos que foram 'planejados e realizados deliberadamente contra a vítima para suprimir sua resistência psíquica e forçá-la a se autoincriminar ou a confessar determinadas condutas delitivas ou para submetê-la a modalidades de castigos adicionais à privação de liberdade em si mesma' "32. Nesse sentido, quando da avaliação da gravidade

29 Veja-se o caso Juan Humber Sánchę vs. Honduras (2003) (CORTE INTERAMERICANA DE DERECHOS HUMANOS. Cuadernillo de Jurisprudencia de la Corte Interamericana de Derechos Humanos $n^{\circ}$ 9: personas privadas de liberdad. p. 6-7. Disponível em: <http://www. corteidh.or.cr/sitios/libros/todos/docs/privados9.pdf $>$. Acesso em: 30 jun. 2017.).

30 Entendimento reafirmado no caso Cantoral Benavides vs. Peru (2000), (CORTE INTERAMERICANA DE DERECHOS HUMANOS. Cuadernillo de Jurisprudencia de la Corte Interamericana de Derechos Humanos $n^{\circ}$ 9: personas privadas de liberdad. p. 11. Disponível em: <http://www.corteidh.or.cr/sitios/libros/todos/docs/privados9.pdf >. Acesso em: 30 jun. 2017.).

31 CORTE INTERAMERICANA DE DERECHOS HUMANOS. Cuadernillo de Jurisprudencia de la Corte Interamericana de Derechos Humanos $n^{\circ}$ 9: personas privadas de liberdad. p. 18. Disponível em: <http://www.corteidh.or.cr/sitios/libros/todos/docs/privados9.pdf>. Acesso em: 30 jun. 2017.

32 Assim como a CorteIDH explicitou no julgamento do caso Tibi vs. Ecuador (2004). Tradução livre para o português do original: "[Son reconocidas cómo] torturas físicas y psíquicas aquellos actos que han sido preparados y realizados deliberadamente contra la víc- 
dos atos que podem ser considerados como cruéis, degradantes ou desumanos, é necessário que sejam considerados todos os elementos e circunstâncias do caso, como a duração dos maus tratos, seus efeitos psíquicos e físicos, bem como aspectos subjetivos da vítima (como sexo, idade e estado de saúde) ${ }^{33}$. Com base nessas considerações, há como elementos constitutivos do crime de tortura: um ato intencional; que cause significativos sofrimentos físicos ou psíquicos; e que tenha sido cometido com determinado fim ou propósito. ${ }^{34}$

Em virtude da gravidade do crime de tortura, que é considerado um crime contra a humanidade, o Sistema Interamericano reconhece a possibilidade de relativização dos meios de prova, admitindo a utilização de provas circunstanciais, de indícios e de presunções para fundamentar a sentença. ${ }^{35}$ Isso, especialmente considerando o desequilíbrio existente entre a vítima e o Estado que perpetrou, ou no mínimo foi conivente, com a prática de tortura. ${ }^{36}$ Daí existir uma pauta regulatória específica para os crimes contra a humanidade, o que refuta a incidência pura a simples de determinações normativas correntes do Direito Penal, como anistia, prescrição

tima para suprimir su resistencia psíquica y forzarla a autoinculparse o a confesar determinadas conductas delictivas o para someterla a modalidades de castigos adicionales a la privación de la libertad en sí misma" (CORTE INTERAMERICANA DE DERECHOS HUMANOS. Cuadernillo de Jurisprudencia de la Corte Interamericana de Derechos Humanos $n^{\circ}$ 9: personas privadas de liberdad. p. 19. Disponível em: <http://www.corteidh.or.cr/sitios/libros/todos/docs/privados9.pdf $>$. Acesso em: 30 jun. 2017.).

33 Entendimento sedimentado no caso penal Miguel Castro Castro vs. Peru (2006), (CORTE INTERAMERICANA DE DERECHOS HUMANOS. Cuadernillo de Jurisprudencia de la Corte Interamericana de Derechos Humanos $n^{\circ}$ 9: personas privadas de liberdad. p. 19. Disponível em: <http://www.corteidh.or.cr/sitios/libros/todos/ docs/privados9.pdf>. Acesso em: 30 jun. 2017.).

34 Enumeração destacada no caso Bueno Alves vs. Argentina (2007) e no caso Espinoza Gonzáles vs. Peru (2014), (CORTE INTERAMERICANA DE DERECHOS HUMANOS. Cuadernillo de Jurisprudencia de la Corte Interamericana de Derechos Humanos $n^{\circ}$ 9: personas privadas de liberdad. p. 20 e 22. Disponível em: <http://www.corteidh. or.cr/sitios/libros/todos/docs/privados9.pdf $>$. Acesso em: 30 jun. 2017.).

35 CORTE INTERAMERICANA DE DERECHOS HUMANOS. Cuadernillo de Jurisprudencia de la Corte Interamericana de Derechos Humanos $n^{\circ}$ 9: personas privadas de liberdad. p. 27. Disponível em: <http://www.corteidh.or.cr/sitios/libros/todos/docs/privados9.pdf $>$. Acesso em: 30 jun. 2017.

36 Destaque-se que, no caso de crimes de contra a humanidade, é necessário haver a inversão do ônus da prova, conforme já defendemos (MEYER, Emilio Peluso Neder. Crimes contra a humanidade, justiça de transição e Estado de Direito: revisitando a ditadura brasileira. Brasiliana - Journal for Brazilian Studies, v. 4, n. 1, p. 225, 2015.). e mesmo modos favoráveis de cumprimento de pena. ${ }^{37}$

A CorteIDH e a CIDH reconhecem, ainda, o caráter de jus cogens da proibição à tortura, que, por esse motivo, é considerada inderrogável, aplicável a todos os Estados em quaisquer circunstâncias e não admite a figura do objetor persistente. Portanto, a proibição da tortura independeria de previsão em tratados ou convenções internacionais, por consistir em um dos princípios basilares do Direito Internacional. Na sentença do caso Tibe vs. Ecuador (2004), a Corte indica que:

Existe um regime jurídico internacional de proibição
absoluta de todas as formas de tortura, tanto física
como psicológica, regime que pertence, hoje em dia,
ao domínio do jus cogens. A proibição da tortura á
completa e inderrogável, ainda nas circunstâncias
mais difíceis, tais quais guerra, ameaça de guerra,
luta contra o terrorismo e quaisquer outros
delitos, estado de sítio ou de emergência, comoção
ou conflito interno, suspensão de garantias
constitucionais, instabilidade política interna ou
outras emergências ou calamidades públicas ${ }^{38}$.

Assim, tanto a prática de tortura, como a imposição de outros tratamentos ou penas cruéis implicam em violação a norma peremptória do Direito Internacional, ${ }^{39}$

37 "Há um reconhecimento já efetivo dessa prática que caminha em um sentido sem retorno, passando a referida estrutura a ser parte de um direito doméstico "acostumado" (ainda que lentamente) a um genuíno Direito Internacional dos Direitos Humanos. Como bem observado por Marcelo D. Torelly, há uma progressiva incorporação de uma norma global de responsabilização individual nos diversos processos que Vicki Jackson classificou como de convergência, de articulação e de resistência. A questão é que se pode ir além, para perceber a introspecção de uma mais ampla estrutura normativa dos crimes contra a humanidade (MEYER, Emilio Peluso Neder. O constitucionalismo brasileiro perante as exigências do Direito Internacional dos Direitos Humanos: diálogos a respeito do sentido adequado de uma unidade na pluralidade normativa. In: MEYER, Emilio Peluso Neder; REPOLÊES, Maria Fernanda Salcedo; RAMOS, Paulo Roberto Barbosa (Orgs.). Teoria Constitucional. Florianópolis: CONPEDI, 2015).

38 Tradução livre para o Português do original: "Existe un régimen jurídico internacional de prohibición absoluta de todas las formas de tortura, tanto física como psicológica, régimen que pertenece hoy día al dominio del ius cogens. La prohibición de la tortura es completa e inderogable, aun en las circunstancias más difíciles, tales como guerra, amenaza de guerra, lucha contra el terrorismo y cualesquiera otros delitos, estado de sitio o de emergencia, conmoción o conflicto interior, suspensión de garantías constitucionales, inestabilidad política interna u otras emergencias o calamidades públicas." (CORTE INTERAMERICANA DE DERECHOS HUMANOS. Cuadernillo de Jurisprudencia de la Corte Interamericana de Derechos Humanos $n^{\circ}$ 10: personas privadas de liberdad. p. 14. Disponível em: <http://www.corteidh.or.cr/sitios/libros/todos/docs/privados9.pdf $>$. Acesso em: 30 jun. 2017).

39 CORTE INTERAMERICANA DE DERECHOS HUMANOS. Cuadernillo de Jurisprudencia de la Corte Interamericana de Dere- 
requerendo dos Estados a devida investigação e responsabilização dos envolvidos. Isto considerando que a responsabilização individual dos envolvidos não exime a responsabilização do Estado quando aqueles que aplicaram torturas e outros tratamentos cruéis agiram na condição de agentes estatais. Portanto, cumpre ao Estado garantir as devidas reparações às vítimas pelos danos materiais e psicológicos, o que perpassa o fornecimento de tratamentos psicológicos e atenção médica. Além disso, o Estado também deve adotar medidas de não repetição, o que perpassa desde a incorporação no ordenamento interno da proibição à tortura até a implementação de protocolos de atuação e a realização de capacitação dos agentes estatais.

\subsection{Desaparecimento forçado}

Como exposto no "Cuadernillo de Jurispruedencia de la Corte Interamericana n. 6: Desaparición Forzada", 40 o desaparecimento forçado consiste em uma violação múltipla e complexa de direitos humanos, que se dá de forma continuada, o que faz com que ela seja considerada de especial gravidade. O seu caráter múltiplo e complexo é expressamente reconhecido desde o julgamento do caso Velásquez Rodríguez vs. Honduras, $1988^{41}$. De modo semelhante, no caso Radilla Pacheco vs. México, cuja sentença é de 23 de novembro de 2009, a Corte aponta como sendo elementos constitutivos do crime de desaparecimento forçado a privação de liberdade, a existência de uma atuação direta de agentes estatais ou, no mínimo, sua aquiescência para com a prática e a negativa de se reconhecer a detenção ou revelar o que se sucedeu com a vítima ${ }^{42}$.

chos Humanos $n^{\circ}$ 10: personas privadas de liberdad. p. 17. Disponível em: <http://www.corteidh.or.cr/sitios/libros/todos/docs/privados9.pdf $>$. Acesso em: 30 jun. 2017

40 CORTE INTERAMERICANA DE DERECHOS HUMANOS. Cuadernillo de Jurisprudencia de la Corte Interamericana de Derechos Humanos $N^{0}$ 6: Desaparición Forzada. p.4. Disponível em: $<$ http://www.corteidh.or.cr/tablas/r33824.pdf >. Acesso em: 3 dez. 2016.

41 CORTE INTERAMERICANA DE DERECHOS HUMANOS. Cuadernillo de Jurisprudencia de la Corte Interamericana de Derechos Humanos $N^{0}$ 6: Desaparición Forzada. p. 8-13. Disponível em: $<$ http://www.corteidh.or.cr/tablas/r33824.pdf $>$. Acesso em: 3 dez. 2016.

42 CORTE INTERAMERICANA DE DERECHOS HUMANOS. Cuadernillo de Jurisprudencia de la Corte Interamericana de Derechos Humanos $N^{o}$ 6: Desaparición Forzada. p.4. Disponível em: $<$ http://www.corteidh.or.cr/tablas/r33824.pdf>. Acesso em: 3 dez. 2016.
Tanto a Comissão como a Corte Interamericana estabeleceram que o desaparecimento forçado de pessoas tem um caráter permanente ou continuado que afeta uma pluralidade de direitos, tais quais o direito à liberdade pessoal, à integridade pessoal, à vida e ao reconhecimento da personalidade jurídica. Dessa forma, foi indicado que o ato de desaparecimento e sua execução iniciam-se com a privação de liberdade da pessoa e a subsequente falta de informação sobre seu destino, e permanece enquanto não seja conhecido o paradeiro da pessoa desaparecida ou sejam identificados com certeza os seus restos. Em suma, ambos os órgãos sustentaram que a prática do desaparecimento forçado implica em um abandono crasso dos princípios essenciais em que se fundamenta o sistema interamericano de direitos humanos e cuja proibição alcançou o caráter de jus cogens ${ }^{43}$.

Em virtude do reconhecimento dessa especial gravidade, também no caso Velásquez, Rodríguez vs. Honduras, começou a ser consolidado o entendimento de que a Corte não necessitaria do mesmo rigor técnico para avaliar as provas das denúncias de casos de desaparecimento forçado que seria esperado de um tribunal nacional. ${ }^{44}$ Aqui não se pretende justificar que cortes internacionais venham a dispor de amplos poderes discricionários, contudo, é preciso reconhecer que, nos casos que envolvem desaparecimento forçado, os familiares das vítimas já se encontram em uma posição fragilizada dada as reiteradas negativas dos Estados em buscar a responsabilização dos envolvidos. E, por ser uma prática que conta, no mínimo, com a tolerância de agentes estatais, a vulnerabilidade das vítimas e a dificuldade

43 Tradução livre para o Português do original: "Tanto la Comisión como la Corte Interamericana han establecido que la desaparición forzada de personas tiene un carácter permanente o continuado que afecta una pluralidad de derechos, tales como el derecho a la libertad personal, a la integridad personal, a la vida y al reconocimiento a la personalidad jurídica. De esta forma, se ha indicado que el acto de desaparición y su ejecución inician con la privación de la libertad de la persona y la subsiguiente falta de información sobre su destino, y permanece mientras no se conozca el paradero de la persona desaparecida o se identifiquen con certeza sus restos. En suma, ambos órganos han sostenido que la práctica de la desaparición forzada implica un craso abandono de los principios esenciales en que se fundamenta el sistema interamericano de derechos humanos36 y cuya prohibición ha alcanzado el carácter de jus cogens" (COMISIÓN INTERAMERICANA DE DERECHOS HUMANOS. Derecho a la verdad en América. p. 25-26. Disponível em: <http://www.oas. org/es/cidh/informes/pdfs/Derecho-Verdad-es.pdf $>$. Acesso em: 3 dez. 2016.).

44 CORTE INTERAMERICANA DE DERECHOS HUMANOS. Cuadernillo de Jurisprudencia de la Corte Interamericana de Derechos Humanos $N^{o}$ 6: Desaparición Forzada. p. 18. Disponível em: $<$ http://www.corteidh.or.cr/tablas/r33824.pdf>. Acesso em: 3 dez. 2016. 
de se obter o acesso a um vasto espectro probatório tornam-se ainda mais evidentes, como já ressaltado no caso da prática de tortura.

A jurisprudência da Corte Interamericana, com reflexos no entendimento da CIDH, também apresenta como direitos violados pela prática do desaparecimento forçado o direito à vida, à liberdade pessoal, à integridade pessoal e ao reconhecimento da personalidade. Ressalte-se que a jurisprudência foi se desenvolvendo no sentido de reconhecer que as violações não se limitam à vítima direta do desaparecimento forçado, mas atingem também seus familiares, o que possui importantes reflexos no reconhecimento do direito à verdade, ${ }^{45}$ que pode ser compreendido em sua perspectiva mais individualizada ou a partir de uma dimensão coletiva. Pela ótica individual, os familiares do desaparecido têm o direito de conhecer o destino que lhe foi dado; já a dimensão coletiva indica que, na medida em que uma prática sistematizada de desaparecimentos forçados compõe a história de um país, é direito de toda a sociedade conhecer essa história e suas implicações. O direito à verdade, como um direito dos familiares, um instrumento de conscientização social e uma ferramenta de não repetição, é solidificado no caso Gómez Palomino vs. Peru, cuja sentença é de 22 de novembro de 2005.

Importante destacar que o direito à verdade começou a ser reconhecido pela CIDH e pela CorteIDH nos casos referentes a desaparecimentos forçados. Assim, a Corte reconheceu que a privação do acesso às informações sobre o paradeiro do familiar desaparecido constitui tratamento desumano e cruel e que a localização e identificação das vítimas de desaparecimento forçado contribui para o enaltecimento da dignidade e da história tanto dos desaparecidos como de suas famílias. ${ }^{46}$

No que se refere aos direitos dos familiares dos desaparecidos, no caso Blake Vs. Guatemala, cuja sentença é de 24 de janeiro de 1998, foi reconhecido o direito a uma investigação efetiva do crime, à responsabilização dos envolvidos e à aplicação das sanções legalmente

45 CORTE INTERAMERICANA DE DERECHOS HUMANOS. Cuadernillo de Jurisprudencia de la Corte Interamericana de Derechos Humanos $N^{o}$ 6: Desaparición Forzada. p. 21. Disponível em: $<$ http://www.corteidh.or.cr/tablas/r33824.pdf>. Acesso em: 3 dez. 2016.

46 Entendimento que também é adotado pela Comissão Interamericana (COMISIÓN INTERAMERICANA DE DERECHOS HUMANOS. Derecho a la verdad en América. p. 30-31. Disponível em: $<$ http://www.oas.org/es/cidh/informes/pdfs/Derecho-Verdades.pdf $>$. Acesso em: 3 dez. 2016.). previstas, bem como ao recebimento de indenização pelos danos e prejuízos sofridos ${ }^{47}$. No caso dos 19 Comerciantes vs. Colômbia, cuja sentença é de 5 de julho de 2004, foi ainda definido que "O direito à justiça não se esgota com o trâmite de processos internos, senão que é devido assegurar em tempo razoável o direito da vítima ou de seus familiares saberem a verdade sobre o que se sucedeu e sancionar os eventuais responsáveis". 48

A Corte, em sua jurisprudência, também analisou as obrigações dos Estados em face de casos de desaparecimento forçado, com base nas ideias de garantias, prevenção, investigação e sanção aos responsáveis, assim como a obrigação dos Estados em adequarem suas legislações internas aos padrões normativos internacionais, especialmente no que se refere à tipificação do crime de desaparecimento forçado. ${ }^{49}$ No caso Gómez Palomino vs. Perú, cuja sentença é de 22 de novembro de 2005, a Corte indica que esse dever de adequar a legislação nacional às disposições da Convenção Americana é primordial para que se efetive a erradicação da prática do desaparecimento forçado. ${ }^{50}$

Também, no caso Velásquez Rodríguez vs. Honduras, é determinada a responsabilidade estatal em promover o respeito às disposições da Convenção Americana sobre Direitos e Deveres do Homem, o que não permitiria que o Estado fosse conivente ou mesmo promovesse a prática do desaparecimento forçado. ${ }^{51}$ Ainda

47 CORTE INTERAMERICANA DE DERECHOS HUMANOS. Cuadernillo de Jurisprudencia de la Corte Interamericana de Derechos Humanos $N^{o}$ 6: Desaparición Forzada. p. 35. Disponível em: $<$ http://www.corteidh.or.cr/tablas/r33824.pdf>. Acesso em: 3 dez. 2016.

48 Tradução livre para o Português do original: "El derecho de acceso a la justicia no se agota en que se tramiten procesos internos, sino que debe además asegurar en tiempo razonable, el derecho de la víctima o sus familiares a saber la verdad de lo sucedido y a que se sancione a los eventuales responsables" ( CORTE INTERAMERICANA DE DERECHOS HUMANOS. Cuadernillo de Jurisprudencia de la Corte Interamericana de Derechos Humanos $N^{o}$ 6: Desaparición Forzada. p. 5. Disponível em: <http://www.corteidh.or.cr/tablas/ r33824.pdf $>$. Acesso em: 3 dez. 2016).

49 CORTE INTERAMERICANA DE DERECHOS HUMANOS. Cuadernillo de Jurisprudencia de la Corte Interamericana de Derechos Humanos $N^{o}$ 6: Desaparición Forzada. p. 45. Disponível em: $<$ http://www.corteidh.or.cr/tablas/r33824.pdf>. Acesso em: 3 dez. 2016

50 CORTE INTERAMERICANA DE DERECHOS HUMANOS. Cuadernillo de Jurisprudencia de la Corte Interamericana de Derechos Humanos $N^{o}$ 6: Desaparición Forzada. p. 60. Disponível em: $<$ http://www.corteidh.or.cr/tablas/r33824.pdf>. Acesso em: 3 dez. 2016.

51 CORTE INTERAMERICANA DE DERECHOS HUMANOS. Cuadernillo de Jurisprudencia de la Corte Interamericana de Dere- 
nesse caso, ficou reconhecido que o dever do Estado de prevenir violações de direitos humanos perpassa ações em todas as esferas, sejam elas jurídicas, administrativas, políticas ou culturais (CorteIDH, 2015, p. 48), e que o dever de investigação, mesmo sendo uma obrigação de meio, deve ser executado de forma séria e comprometida, de modo que não basta a promulgação de uma sentença condenatória dos envolvidos, é necessário que o Estado tenha se comprometido com a efetiva solução da questão (CorteIDH, 2015, p. 49).

Em suma, a jurisprudência da Corte Interamericana de Direitos Humanos e, por consequência, da Comissão Interamericana, reconhece como direitos afrontados por meio da prática do crime de desaparecimento forçado, no que concerne ao indivíduo vítima do desaparecimento, o direito à liberdade pessoal, à integridade, à vida e ao reconhecimento de sua personalidade jurídica. Já com relação à família da vítima, são violados o direito à justiça, à verdade e à integridade pessoal dos próprios familiares.

Ainda há o reconhecimento do dever do Estado em garantir a efetivação dos direitos previstos na Convenção Americana sobre Direitos e Deveres do Homem e em outros instrumentos internacionais sobre a matéria, o dever de instituir medidas de prevenção ao cometimento do crime de desaparecimento forçado, de utilizar todos os mecanismos disponíveis para investigar os casos de desaparecimento, de sancionar os responsáveis por seu cometimento e de adequar sua legislação interna no que concerne à tipificação desse crime. ${ }^{52}$

Também é reconhecida a necessidade de que o estado repare as vítimas e seus familiares pelos danos sofridos, sejam eles materiais ou não. Entretanto, como essa prática possui reflexos não só para os indivíduos diretamente afetados, como também para a sociedade que vivencia sua ocorrência - que sucede de forma sistemática - a CorteIDH e a CIDH reconhecem a necessidade de implementação de medidas que visem assegurar a satisfação dos direitos dos afetados e a não repetição dessa modalidade de crime. Dentre essas medidas, a Corte destaca a busca e identificação dos restos mortais das vítimas; o fornecimento de tratamentos fí-

chos Humanos $N^{o}$ 6: Desaparición Forzada. p. 45. Disponível em: $<$ http://www.corteidh.or.cr/tablas/r33824.pdf $>$. Acesso em: 3 dez. 2016

52 Deveres reconhecidos tanto pela Comissão como pela Corte Interamericana. sicos e psicológicos aos familiares; a criação de bancos de dados genéticos, que facilitaria a identificação dos corpos quando localizados; a realização de atos e criação de monumentos em memória às vítimas de desaparecimento forçado; a promoção de uma formação dos agentes públicos baseada no respeito aos direitos humanos; e o acesso público a arquivos estatais.

Ressalte-se, ainda, que, de acordo com o entendimento da CIDH e da CorteIDH,

[...] os Estados devem abster-se de recorrer a figuras como a anistia em benefício dos autores, assim como alguma outra disposição análoga, tais quais a aplicação ilegítima da prescrição, irretroatividade da lei penal, coisa julgada, ne bis in idem, a aplicação da jurisdição penal militar ou qualquer mecanismo semelhante que exime a responsabilidade. ${ }^{53}$

Assim, o sistema interamericano de proteção aos direitos humanos reconhece o caráter imprescritível dos crimes de desaparecimento forçado, dada a sua qualificação como crime contra a humanidade, que é reflexo de seu reconhecimento como norma peremptória do Direito Internacional. Daí que também não seriam aplicáveis as figuras da coisa julgada e da irretroatividade da lei penal no tempo.

É importante também destacar que o entendimento prevalecente no Sistema Interamericano de Direitos Humanos não destoa de práticas internacionais mais amplas. Naomi Roht-Arriaza sustenta, desde o início da década de 1990, que há uma responsabilidade estatal internacional de investigação e persecução de desaparecimentos, esquadrões da morte e outras graves violações de direitos humanos praticadas por regimes opressores. Já naquele momento, ela destacava a incidência de um direito costumeiro internacional capaz de fundamentar um dever para com a verdade. Ele estaria assentado em: a) tratados internacionais que poderiam gerar obrigações mesmo para Estados não signatários, reconhecendo tais normas um direito a uma solução judicial (right to a remedy); b) práticas estatais, tais quais a persecução de perpetradores, a formação de um direito doméstico

53 Tradução livre para o português do original: “[...] los Estados deben abstenerse de recurrir a figuras como la amnistía en beneficio de los autores, así como alguna otra disposición análoga tales como la aplicación ilegítima de la prescripción, irretroactividad de la ley penal, cosa juzgada, ne bis in idem, la aplicación de la jurisdicción penal militar o cualquier eximente similar de responsabilidad" (COMISIÓN INTERAMERICANA DE DERECHOS HUMANOS. Derecho a la verdad en América. p. 29. Disponível em: <http://www. oas.org/es/cidh/informes/pdfs/Derecho-Verdad-es.pdf>. Acesso em: 3 dez. 2016.). 
conforme as normas internacionais de direitos humanos, as declarações de representantes governamentais, resoluções e declarações de organizações internacionais; e, c) a responsabilidade estatal pelos atos de seus agentes que consistam em graves violações de direitos humanos. ${ }^{54}$

Em sentido equivalente, Cherif Bassiouni também defendera, em meados da década de 1990, uma estrutura normativa a partir da qual teríamos a formação de direitos e obrigações estatais concernentes à prática de crimes contra a humanidade. Tal estrutura tem caráter de norma imperativa de jus cogens e determina obrigações erga omnes. Especificamente, ela determinaria: ${ }^{55}$

a)a obrigação de persecução ou extradição;

b)fornecimento de assistência jurídica;

c)a eliminação de cláusulas de afastamento da norma penal (statutes of limitations, como as auto-anistias);

d)a eliminação de imunidades estatais;

e)e, adicionaríamos com Roht-Arriaza, a obrigação de inversão do ônus da prova em favor da vítima e em desfavor do Estado.

Vê-se que há a consolidação de um direito costumeiro internacional que determina, de um lado, a proteção regional dos direitos humanos e, de outro, a própria ordem doméstica; aplicar a "regra 2x1" é uma violação desse sistema normativo. Tal costume internacional, de modo algum, conflita com a ordem jurídica doméstica, somando a essa normativa elementos de jus cogens e obrigações erga omnes. Como adverte Bryers, os elementos que formam o Direito Costumeiro Internacional são de duas ordens: a) a presença de uma consistente e geral prática estatal; b) a confirmação por parte dos Estados de que aquela prática está de acordo com o direito (opinio juris sive necessitatis). ${ }^{56}$

Há um reconhecimento já efetivo dessa prática, passando a referida estrutura a ser parte de um direito

54 ROHT-ARRIAZA, Naomi. State Responsibility to Investigate and Prosecute Grave Human Rights Violations in International Law. California Law Review, n. 78, p. 449, 1990.

55 BASSIOUNI, M. Cherif. Searching for peace and achieving justice: the need for Accountability". Law and Contemporary Problems, v. 59, n. 4, 1996, p. 17. Também, BASSIOUNI, M. Cherif. International crimes: jus cogens and Obligatio Erga Omnes. Law and Contemporary Problems, v. 59, n. 4, p. 63, 1996.

56 BRYERS, Michael. Custom, power and the power of rules: international relations and customary international law. Cambridge: Cambridge University Press, 1999. p. 130. doméstico "acostumado" (ainda que lentamente) a um genuíno Direito Internacional dos Direitos Humanos. Como bem observado por Marcelo D. Torelly, há uma progressiva incorporação de uma norma global de responsabilização individual nos diversos processos que Vicki Jackson classificou como de convergência, de articulação e de resistência. ${ }^{57}$ A questão é que esse caminho pode ser tensionado por práticas regressivas que devem ser enfrentadas por atores sociais.

\subsection{Aplicação da "regra $2 \times 1$ "}

A aplicação da chamada "regra 2x1" aos casos de cometimento de crimes lesa humanidade ocorridos durante a última ditadura argentina perpassa uma questão central que é a necessidade de que os Estados assegurem a possibilidade material de responsabilização e aplicação de uma pena proporcional aos envolvidos nesses crimes. Portanto, a pergunta a ser feita vai além dos questionamentos sobre a incidência ou não da Lei n. 24.390/1994 no caso Luis Muiña e refere-se à conformidade (ou inconformidade) com os dispositivos internacionais de proteção dos direitos humanos da aplicação da "regra $2 \times 1$ ".

Primeiramente, é necessário observar que, de acordo com o entendimento solidificado pela CorteIDH e pela $\mathrm{CIDH}$ e apresentado anteriormente, os crimes imputados a Luis Muiña não consistem em crimes comuns, mas se referem a uma categoria especial de violações a direitos humanos prevista no direito internacional. A privação arbitrária de liberdade representa uma violação à integridade e à dignidade humana, que são direitos inderrogáveis dos indivíduos, independentemente de quaisquer circunstâncias. A tortura, por sua vez, representa violação a norma de jus cogens, sendo vedada em quaisquer circunstâncias independente de previsão em tratados ou convenções internacionais. E o desaparecimento forçado, também, representa caso de violação de norma de jus congens, por consistir em violação aos pilares das normas internacionais de proteção dos direitos humanos. Considera-se, assim, que foram

57 TORELLY, Marcelo D. A formação da norma global de responsabilidade individual: mobilização política transnacional, desenvolvimento principiológico e estruturação em regras internacionais e domésticas. In: MEYER, Emilio Peluso Neder; OLIVEIRA, Cattoni de (Orgs.). Justiça de transição nos 25 anos da Constituição de 1988. 2. ed. Belo Horizonte: Initia Via, 2014. p. 479.; JACKSON, Vicki. Constitutional engagement in a Transnational Era. New York: Oxford University Press, 2009. 
praticados crimes contra a humanidade, cujo interesse na investigação e responsabilização dos envolvidos ultrapassa as vítimas diretas, tornando-se uma matéria de interesse internacional.

Por esses motivos, reconhece-se que os crimes em questão não são passíveis de anistia ou de prescrição, ${ }^{58}$ cabendo aos Estados promover, utilizando-se de todos os meios e instrumentos lícitos disponíveis, a investigação dos fatos ocorridos, a responsabilização dos agentes responsáveis e a reparação às vítimas.

Dessa forma, a aplicação da "regra 2x1" no caso Luis Muiña e em qualquer outro caso que envolve o cometimento de crimes lesa humanidade também se mostra indevida, por impedir a aplicação das penas devidas aos responsáveis. Esse dispositivo processual possibilitaria que não se concretizasse a demanda por efetiva responsabilização dos envolvidos e pela aplicação de uma pena proporcional aos crimes cometidos.

Nesse sentido, o Grupo de Trabalho sobre os Desaparecimentos Forçados ou Involuntários e o Relator Especial sobre a Promoção da Verdade, da Justiça, a Reparação e as Garantias de Não Repetição ligados ao Alto Comissariado para os Direitos Humanos das Nações Unidas, emitiram um comunicado ao governo argentino, ${ }^{59}$ à Suprema Corte de Justiça e à comunidade internacional alertando sobre os riscos relacionados à aplicação da Lei n. 24.390/1994 aos casos de crimes lesa humanidade e demandando que a Suprema Corte de Justiça reveja seu posicionamento com base na Lei n. 27.362/2017, recentemente aprovada. O objetivo desse comunicado era:

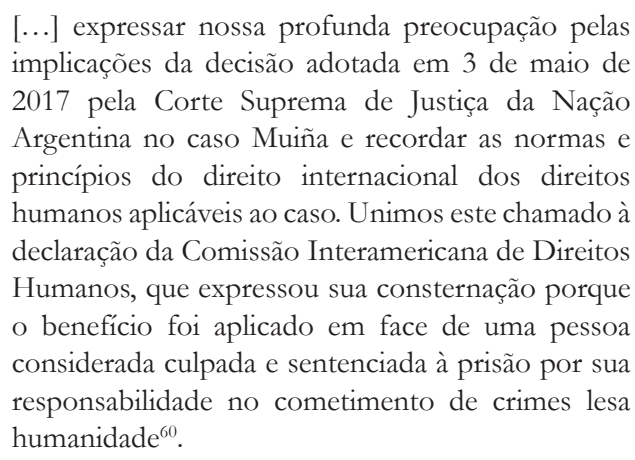

58 GRUPO de trabajo sobre las desapariciones forzadas o involuntárias; relator especial sobre la promoción de la verdad, la justicia, la reparación y las garantías de no repetición. OL ARG 3/2017. 15 jun. 2017. p.6.

59 GRUPO de trabajo sobre las desapariciones forzadas o involuntárias; relator especial sobre la promoción de la verdad, la justicia, la reparación y las garantías de no repetición. OL ARG 3/2017. 15 jun. 2017.

60 Tradução livre para o Português do original: "[Quisiéramos]
Ressalta-se, ainda, que, como destacado pelo Grupo de Trabalho sobre os Desaparecimentos Forçados ou Involuntários e pelo Relator Especial sobre a Promoção da Verdade, da Justiça, a Reparação e as Garantias de Não Repetição, ${ }^{61}$ a aplicação da "regra 2x1" favoreceria um ambiente de impunidade em relação aos crimes cometidos durante o período ditatorial, o que seria especialmente grave no contexto argentino, que foi marcado por uma intensa luta pela superação da Lei de Obediência Devida e da Lei do Ponto Final, que consistiam em obstáculos à responsabilização dos agentes envolvidos em violações a direitos humanos. ${ }^{62}$

Com base no direito internacional dos direitos humanos, observa-se que a aplicação da "regra 2x1" nos casos que envolvem o cometimento de crimes lesa humanidade fragiliza a obrigação dos Estados em impor sanções apropriadas aos responsáveis, a obrigação de impor uma sanção proporcional e os limites que devem ser impostos aos indultos e à comutação das penas nos casos de crimes lesa humanidade ${ }^{63}$.

Como consagrado na jurisprudência da CorteIDH e da CIDH, os Estados não têm, apenas, a obrigação de impor penas àqueles indivíduos responsáveis por violações a direitos humanos, em especial pelo cometimento de crimes lesa humanidade, mas as penas impostas devem ser adequadas e proporcionais aos crimes perpetrados. Isso, de forma a assegurar que as penas impostas não consistam em um fator de impunidade e contribuam para a construção de um ambiente de não repetição.

expresar nuestra profunda preocupación por las implicaciones de la decisión adoptada el 3 de mayo de 2017 por la Corte Suprema de Justicia de la Nación Argentina en el caso Muiña y recordar las normas y principios del derecho internacional de los derechos humanos aplicables en este caso. Unimos este llamado a la declaración de la Comisión Interamericana de Derechos Humanos, que expresó su consternación porque el beneficio haya sido aplicado respecto de una persona encontrada culpable y sentenciada a prisión por su responsabilidad en la comisión de crímenes de lesa humanidad" (GRUPO de trabajo sobre las desapariciones forzadas o involuntárias; relator especial sobre la promoción de la verdad, la justicia, la reparación y las garantías de no repetición. OL ARG 3/2017. 15 jun. 2017.p. 2).

61 GRUPO de trabajo sobre las desapariciones forzadas o involuntárias; relator especial sobre la promoción de la verdad, la justicia, la reparación y las garantías de no repetición. OL ARG 3/2017. 15 jun. 2017.p. 3.

62 MEYER, Emilio Peluso Neder. Ditadura e responsabilização: elementos para uma justiça de transição no Brasil. Belo Horizonte: Arraes Editor, 2012. p. 88.

63 MEYER, Emilio Peluso Neder. Ditadura e responsabilização: elementos para uma justiça de transição no Brasil. Belo Horizonte: Arraes Editor, 2012. p. 4. 
Ademais, o Direito Internacional restringe a aplicabilidade de institutos processuais como a anistia e os indultos no caso de crimes contra a humanidade. Essa restrição à aplicação de benefícios processuais teria como objetivo promover a luta contra a impunidade e evitar que essas normas processuais tornem-se obstáculos à efetivação da justiça. ${ }^{64}$ Assim, "o Comitê de Direitos Humanos rechaça todo tipo de imunidade e considera que deve-se eliminar todos os impedimentos para estabelecer a responsabilidade jurídica de pessoas que cometeram graves violações a direitos humanos". ${ }^{65}$ Também o Sistema Interamericano de Direitos Humanos não reconhece a aplicação de todos os benefícios processuais aos envolvidos em graves violações de direitos humanos, ressaltando a importância de que esse benefícios não proporcionem a impunidade aos envolvidos. ${ }^{66}$

Desse modo, como salientado pelo Grupo de Trabalho sobre os Desaparecimentos Forçados ou Involuntários e pelo Relator Especial sobre a Promoção da Verdade, da Justiça, a Reparação e as Garantias de Não Repetição:

A partir uma perspectiva de direitos humanos, a obrigação de investigar e processar emana do direito a um recurso efetivo, que forma parte dos direitos da vítima, de seus familiares mais próximos e, em certos casos, de toda a sociedade, em conhecer a verdade. Assim mesmo, quisemos ressaltar que a administração da justiça frente a graves violações de direitos humanos é um elemento central para evitar a recorrência das ditas violações e que promover uma cultura de impunidade contribui a criar ciclos viciosos de violência. ${ }^{67}$

64 GRUPO de trabajo sobre las desapariciones forzadas o involuntárias; relator especial sobre la promoción de la verdad, la justicia, la reparación y las garantías de no repetición. OL ARG 3/2017. 15 jun. 2017. p. 6).

65 Tradução livre para o português do original: "[...]el Comité de Derechos Humanos rechaza todo tipo de inmunidad y considera que deben eliminarse todos los impedimentos para establecer la responsabilidad jurídica de personas que han cometido graves violaciones a derechos humanos." (GRUPO de trabajo sobre las desapariciones forzadas o involuntárias; relator especial sobre la promoción de la verdad, la justicia, la reparación y las garantías de no repetición. $O L$ ARG 3/2017. 15 jun. 2017.p. 6).

66 Para mais informações acerca do entendimento da CorteIDH e da CIDH a esse respeito, CORTE INTERAMERICANA DE DERECHOS HUMANOS. Cuadernillo de Jurisprudencia de la Corte Interamericana de Derechos Humanos $n^{\circ} 10$ : integridad personal. Disponível em: <http://www.corteidh.or.cr/sitios/libros/todos/docs/integridad10.pdf>. Acesso em: 30 jun. 2017.

67 Tradução livre para o português do original: "Desde una perspectiva de derechos humanos, la obligación de investigar y enjuiciar dimana del derecho a un recurso efectivo, que forma parte del dere-
Com base no exposto, observa-se a incompatibilidade da aplicação da "regra 2x1" nos casos que envolvem crimes lesa humanidade, uma vez que esse benefício processual impediria a aplicação de uma pena proporcional aos crimes cometidos, tornando o processo judicial não efetivo por não trazer a efetiva responsabilização penal aos envolvidos. Assim, favorecer-se-ia a construção de um ambiente de impunidade, em relação ao cometimento de crimes que não representam uma afronta apenas ao ordenamento argentino, mas a toda a comunidade internacional.

\section{Override e backlash em um CONSTITUCIONALISMO TRANSNACIONAL}

Alguns importantes aspectos do constitucionalismo contemporâneo podem ser observados nas repercussões do caso Luis Muiña e na superveniência da Lei 27.362/2017. De um lado, há uma inserção de institutos próprios do common law na questão: não se trata, apenas, de uma oposição do legislativo ao judiciário. Ocorreu uma verdadeira atitude de override (a superação de uma decisão judicial por uma decisão legislativa — diverso de um overruling, superação de uma decisão judicial por outra decisão judicial). ${ }^{68}$ Esse tipo de situação aponta para relações às vezes tensas entre os poderes de Estado, relações que penderiam menos para aquelas de um "diálogo institucional". ${ }^{9}$

Quando normas de direitos humanos estão em jogo, mais do que a pura prevalência de posições institucionais, pode ser que um constitucionalismo de caráter transnacional aponte, sim, para a precedência de normas internacionais incriminatórias de crimes contra a humanidade. É daí que não se pode impor, de cima

cho de la víctima, sus familiares más próximos y, en ciertos casos, toda la sociedad, a conocer la verdad. Asimismo, quisiéramos recalcar que la administración de justicia frente a graves violaciones de derechos humanos es un elemento central para evitar la recurrencia de dichas violaciones y que promover una cultura de impunidad contribuye a crear ciclos viciosos de violencia." (GRUPO de trabajo sobre las desapariciones forzadas o involuntárias; relator especial sobre la promoción de la verdad, la justicia, la reparación y las garantías de no repetición. $O L A R G$ 3/2017, p. 3, 15 jun. 2017.).

68 MEYER, Emilio Peluso Neder. Decisão e jurisdição constitucional: crítica às sentenças intermediárias, técnicas e efeitos do controle constitucionalidade em perspectiva comparada. Rio de Janeiro: Lumen Juris, 2017. p. 209.

69 BRANDÃO, Rodrigo. Supremacia judicial versus diálogos institucionais. 2. ed. Rio de Janeiro: Lumen Juris, 2016. 
abaixo, determinações contrárias àquelas pretendidas pelos principais atores envolvidos na consolidação de uma determinada normativa. O risco é sempre o de uma reação, de um backlash. Isto porque boa parte da construção internacionalizada dos direitos humanos deriva da atuação em rede de atores da própria sociedade civil: ativistas, redes de advogados e ONG's que promovem de uma construção de "baixo para cima", ou seja, do nível da sociedade para o nível institucional. ${ }^{70}$ Essa característica é ainda mais sensível no caso da justiça de transição, um campo construído em grande parte pela mobilização transfronteiriça de atores sociais. ${ }^{71}$ Além disso, no que tange à CorteIDH e à CIDH, o funcionamento desses órgãos do Sistema Interamericano é diretamente vinculado à pressão de atores dos Estados-partes que se veem pressionados a se socorrer de instituições supranacionais.

De acordo com as conclusões expostas neste artigo, Engstrom demonstra que, apesar das enormes dificuldades institucionais domésticas de solidificação das decisões e recomendações gestadas no Sistema Interamericano, elas gerarão pressões políticas capazes de mobilizar maior proteção de direitos humanos, como, acreditamos, se deu na reação ao caso Luis Muiña. ${ }^{72}$ Pode ser que o trabalho de uma ONG possa se reduzir a fazer um diagnóstico do andamento processual das ações por crimes contra a humanidade: é assim que Balardini apresenta o trabalho desenvolvido pelo CELS (Center for Legal and Social Studies) em determinar a advocacia no campo da justiça de transição. ${ }^{73}$ A reação ao julgamento da Suprema Corte no caso Luis Muiña apresenta um cenário ainda mais complexo de direta reação social e determinação de uma atuação legislativa.

Papel proeminente para a construção do sentido das

70 KECK, Margareth; SIKKINK, Kathryn. Activists Beyond Borders: advocacy networks in International Politics. New York: Cornell University Press, 1998. Especialmente o capítulo 3.

71 É o que se pode verificar em ARTHUR, Paige. How transitions reshaped human rights: a conceptual history of transitional justice. Human Rights Quaterly, v. 31, p. 321-367, 2009.p. 326.

72 ENGSTROM, Par. Reconceptualising the Impact of the InterAmerican Human Rights System. Rev. Direito e Práx., Rio de Janeiro, v. 8, n. 2, p. 1.272, 2017.

73 BALARDINI, Lorena. Monitoring Human Rights Trials: Information Strategies Developed in Argentina's Transitional Justice Process. Transitional Justice Review, v. 1, n. 4, p. 233-261, 2016. No Brasil, trabalho semelhante de definição da situação de processos por crimes contra a humanidade cometidos na ditadura de 19641985 é desempenhado pelo Centro de Estudos sobre Justiça de Transição da UFMG (https://cjt.ufmg.br/acoes-criminais/, acesso: 21/22/2018). normas constitucionais terão os movimentos sociais. ${ }^{74}$ Reva Siegel toma como exemplo o que representou a derrota, na década de 1970, da proposta de emenda constitucional de iguais direitos para homens e mulheres (Equal Rights Amendment) aprovada em 1972 no Congresso Nacional, mas que não obteve a ratificação dos órgãos legislativos estaduais. O período de ratificação teria sido capaz de difundir um espaço de debate sobre direitos das mulheres que seria fundamental para que o Poder Judiciário institucionalizasse e reconhecesse as pretensões das lutas feministas. O resultado foi um corpo normativo protetivo chamado de de facto ERA.

Esse árduo campo de trabalho daria espaço para o que Siegel chama de cultura constitucional: um conjunto de compreensões sobre a prática argumentativa que guia as interações entre cidadãos e autoridades a respeito do significado da Constituição. ${ }^{75}$ Partindo de uma concepção de democracia muito mais ampla do que apenas a regra da maioria, é possível verificar o engajamento e a discussão de cidadãos a respeito de decisões de outras esferas do Estado, para além da legiferante. Além de atrair a atenção dos cidadãos para o processo de judicialização da Constituição, essas disputas são também disputas sobre um passado institucional de forjará o futuro constitucional.

A chamada cultura constitucional estabelece duas condições para permitir que movimentos sociais participem da disputa sobre o significado da Constituição: a) a condiça do consentimento requer que os participantes da disputa apelem para a própria Constituição ao tentar fazer prevalecer suas perspectivas por meio da persuasão; e, b) a condição do valor público, que requer que os defensores apelem para uma linguagem pré-estabelecida para defender novos postulados a respeito do significado da Constituição, ou seja, é preciso estabelecer que princípios compartilhados já abrigavam a interpretação defendida.

E é dentro desse contexto interpretativo democrático que a crítica à leitura da Constituição feita por uma

74 "Em suma, como salientamos, para o Constitucionalismo Democrático de Post e Siegel, os movimentos sociais constituem uma das mais importantes fontes de mudança de sentidos constitucionais, de forma a legitimar certas práticas sociais e a deslegitimar outras que, muitas vezes, representam compreensões assimétricas de mundo." (BUNCHAFT, Maria Eugênia. Constitucionalismo democrático versus minimalismo judicial. Direito, Estado e Sociedade, n. 38, p.168, 2011.).

75 SIEGEL, Reva B. Constitutional Culture, Social Movement Conflict and Constitutional Change: the case of the De Facto Era. 2005-06. California Law Review, p. 1.325, 2006. 
corte no seio da jurisdição constitucional pode contribuir para a reconstrução interpretativa. Ao invés de comprometer sua autoridade, ela destaca os problemas de uma decisão judicial e força o judiciário a se reinventar. Ou, mesmo, cria condições para que o legislativo se contraponha ao judiciário. É aqui que uma decisão polêmica, embora nunca necessária, pode se gerar o efeito de um backlash, criando novas condições que empurram movimentos sociais contra as instituições, obrigando-as a guiar seu direcionamento em prol de interpretações mais democráticas. ${ }^{76}$ Se é possível que a cultura constitucional redefina como domesticamente ler uma Constituição, no caso latino-americano deve-se adicionar que há uma direta influência da leitura dos sistemas domésticos nos termos do que define o Sistema Interamericano de Direitos Humanos. É claro que isto demanda inúmeros esforços de organizações não governamentais e de outros atores sociais que geram a necessária pressão por exigir que o Estado se mantenha fiel a padrões regionais institucionalizados de direitos humanos. ${ }^{77}$

\section{Considerações finais}

A definição do sentido interpretativo de normas constitucionais e legais depende da construção democrática daqueles por elas envolvidos. Já não é mais possível que instituições estatais - leia-se aqui, o judiciário — ditem de cima para baixo quais são as interpretações prevalecentes. Essa questão ganha especial destaque pela sua figuração em uma normativa de especial caracterização, qual seja, a dos direitos humanos. Mais do

76 "Cidadãos que invocam a Constituição para criticar as cortes associam a Constituição com as compreensões que eles entendem normativamente cogentes e acreditam ser vinculantes para outros. Quando cidadãos falam sobre os compromissos que detêm mais apaixonadamente na linguagem de uma tradição constitucional compartilhada, eles a fortalecem. Desse modo, mesmo a resistência à interpretação judicial pode fomentar a legitimidade democrática da Constituição". Tradução livre de: "Citizens who invoke the Constitution to criticize courts associate the Constitution with understandings they find normatively compelling and believe to be binding on others. When citizens speak about their most passionately held commitments in the language of a shared constitutional tradition, they invigorate that tradition. In this way, even resistance to judicial interpretation can enhance the Constitution's democratic legitimacy." (POST, Robert; SIEGEL, Reva. Roe rage: democratic constitutionalism and backlash. 2007. p. 375).

77 CHILLIER, Gastón. TIMO, Pétalla. The Global Rights Movement in the 21st Century: reflections from the perspective of a National Human Rights NGO from the South. SUR - International Journal on Human Rights, v. 20, p. 378, 2014. que um conjunto de pressuposições valorativas (guiadas pela inúmeras vezes invocada dignidade da pessoa humana), o que se observa é a constituição de um sistema de normas de jus cogens e obrigações erga omnes que "fisgam" a interpretação do dispositivos internacionais, constitucionais e legais. Daí que não se trata de ler o sistema do Direito Internacional dos Direitos Humanos como capaz de produzir diferentes (mas supostamente possíveis) diversas respostas.

Ao grave caráter dos crimes contra a humanidade corresponde uma disciplina normativa que busca a todo tempo evitar sua repetição, tamanha a violação por eles proporcionada. Não incidência de anistia, prescrição e mesmo de regimes e regras de cumprimento de pena fazem parte do combate a graves violações de direitos humanos que, ao contrário de retroceder em números, continuam a crescer assustadoramente na comunidade internacional. Não é de se espantar que isto seja concomitante a retrocessos autoritários. Daí a importância de uma consciente mobilização social capilarizada em diversas organizações que podem pautar a rápida reação a esse contínuo retorno no tempo. Tal mobilização foi exemplarmente apresentada no caso argentino, na medida em que um descompasso judicial doméstico com o Sistema Interamericano de Direitos Humanos foi respondido com uma forte pressão popular e uma reação legislativa corretiva.

\section{ReferênCias}

ARGENTINA. Ministério Público Fiscal. CSJ 1574/2014/RH1. Relator: Min. Horacio Rosatti. 3 de maio de 2017.

ARTHUR, Paige. How transitions reshaped human rights: a conceptual history of transitional justice. $\mathrm{Hu}$ man Rights Quaterly, v. 31, p. 321-367, 2009.

BALARDINI, Lorena. Monitoring Human Rights Trials: Information Strategies Developed in Argentina's Transitional Justice Process. Transitional Justice Review, v. 1, n. 4, p. 233-261, 2016.

BASSIOUNI, M. Cherif. Crimes against humanity: historical evolution and contemporary application. Cambridge: Cambridge University Press, 2011.

BASSIOUNI, M. Cherif. International crimes: jus cogens and Obligatio Erga Omnes. Law and Contemporary 
Problems, v. 59, n. 4, p. 63-74, 1996.

BASSIOUNI, M. Cherif. Searching for peace and achieving justice: the need for Accountability". Law and Contemporary Problems, v. 59, n. 4, 1996, p. 9-28.

BRANDÃO, Rodrigo. Supremacia judicial versus diálogos institucionais. 2. ed. Rio de Janeiro: Lumen Juris, 2016.

BRYERS, Michael. Custom, power and the power of rules: international relations and customary international law. Cambridge: Cambridge University Press, 1999.

BUNCHAFT, Maria Eugênia. Constitucionalismo democrático versus minimalismo judicial. Direito, Estado e Sociedade, n. 38, 2011.

BUSCAGLIA, Teresa Sofía. El Caso Muiña: los argentinos rechazan el atropello a los derechos humanos. The New York Times. Disponível em: < https://www.nytimes. com/es/2017/05/09/el-caso-muina-los-argentinos-rechazan-el-atropello-a-los-derechos-humanos/>. Acesso em: 20 jun. 2017.

CHILLIER, Gastón. TIMO, Pétalla. The Global Rights Movement in the $21^{\text {st }}$ Century: reflections from the perspective of a National Human Rights NGO from the South. SUR - International Journal on Human Rights, v. 20, p. 378, 2014.

\section{COMISIÓN INTERAMERICANA DE DERECHOS} HUMANOS. Derecho a la verdad en América. Disponível em: <http://www.oas.org/es/cidh/informes/pdfs/ Derecho-Verdad-es.pdf $>$. Acesso em: 3 dez. 2016.

CORTE INTERAMERICANA DE DERECHOS HUMANOS. Cuadernillo de Jurisprudencia de la Corte Interamericana de Derechos Humanos $N^{0}$ 6: Desaparición Forzada. Disponível em: <http://www.corteidh.or.cr/ tablas/r33824.pdf>. Acesso em: 3 dez. 2016.

CORTE INTERAMERICANA DE DERECHOS HUMANOS. Cuadernillo de Jurisprudencia de la Corte Interamericana de Derechos Humanos $n^{\circ} 8$ : liberdad personal. Disponível em: <http://www.corteidh.or.cr/sitios/libros/todos/docs/libertadpersonal5.pdf $>$. Acesso em: 30 jun. 2017.

CORTE INTERAMERICANA DE DERECHOS HUMANOS. Cuadernillo de Jurisprudencia de la Corte Interamericana de Derechos Humanos $n^{\circ}$ 9: personas privadas de liberdad. Disponível em: <http://www.corteidh.or.cr/ sitios/libros/todos/docs/privados9.pdf $>$. Acesso em: 30 jun. 2017.
CORTE INTERAMERICANA DE DERECHOS HUMANOS. Cuadernillo de Jurisprudencia de la Corte Interamericana de Derechos Humanos $n^{\circ} 10$ : integridad personal. Disponível em: <http://www.corteidh.or.cr/sitios/ libros/todos/docs/integridad10.pdf $>$. Acesso em: 30 jun. 2017.

ENGSTROM, Par. Reconceptualising the Impact of the Inter-American Human Rights System. Rev. Direito e Práx., Rio de Janeiro, v. 8, n. 2, p. 1.250-1.285, 2017.

GRUPO de trabajo sobre las desapariciones forzadas o involuntárias; relator especial sobre la promoción de la verdad, la justicia, la reparación y las garantías de no repetición. OL $A R G$ 3/2017. 15 jun. 2017.

JACKSON, Vicki. Constitutional engagement in a Transnational Era. New York: Oxford University Press, 2009.

KECK, Margareth; SIKKINK, Kathryn. Activists Beyond Borders: advocacy networks in International Politics. New York: Cornell University Press, 1998.

POR QUÉ está condenado Luis Muiña, el beneficiado del 2x1 tras el fallo de la corte. La Nacion. Disponível em: <http://www.lanacion.com.ar/2020030-por-queesta-condenado-luis-muina-el-beneficiado-del-2x1-trasel-fallo-de-la-corte>. Acesso em: 20 jun. 2017.

MEYER, Emilio Peluso Neder. Crimes contra a humanidade, justiça de transição e Estado de Direito: revisitando a ditadura brasileira. Brasiliana - Journal for Brazilian Studies, v. 4, n. 1, p. 208-242, 2015.

MEYER, Emilio Peluso Neder. Criminal responsibility in Brazilian transitional justice: a constitutional interpretative process under the paradigm of International Human Rights Law. Indonesian Journal of International and Comparative Law, v. IV, p. 41-72, 2017.

MEYER, Emilio Peluso Neder. Decisão e jurisdição constitucional: crítica às sentenças intermediárias, técnicas e efeitos do controle constitucionalidade em perspectiva comparada. Rio de Janeiro: Lumen Juris, 2017.

MEYER, Emilio Peluso Neder. Ditadura e responsabilização: elementos para uma justiça de transição no Brasil. Belo Horizonte: Arraes Editor, 2012.

MEYER, Emilio Peluso Neder. O constitucionalismo brasileiro perante as exigências do Direito Internacional dos Direitos Humanos: diálogos a respeito do sentido adequado de uma unidade na pluralidade normativa. In: MEYER, Emilio Peluso Neder; REPOLÊS, Maria Fernanda Salcedo; RAMOS, Paulo Roberto Barbosa 
(Orgs.). Teoria Constitucional. Florianópolis: CONPEDI, 2015.

EL GOBIERNO promulgó la ley para limitar la aplicación del 2x1 a represores y genocidas. Parlamentario. Disponível em: < http://www.parlamentario.com/noticia-101020.html>. Acesso em: 20 jun. 2017.

PERTOT, Werner. Macri se decidió por la Corte de manga. Disponível em: <https://www.pagina12.com.ar/diario/elpais/1-288291-2015-12-15.html>. Acesso em: 20 jun. 2017.

POLITI, Daniel. Argentines Fight Court's Leniency for Human Rights Crimes. The New York Times. Disponível em: <https://www.nytimes.com/2017/05/13/world/ americas/argentina-mauricio-macri-luis-muia.html $>$. Acesso em: 20 jun. 2017.

POST, Robert; SIEGEL, Reva. Roe rage: democratic constitutionalism and backlash. 2007.

PUGLIESE, Yuri. Lei brasileira da anistia: os conflitos entre o acordo social e a cooperação internacional. Revista de Direito Internacional, Brasília, v. 9, n. 2, p. 93-113, jul./dez. 2012.

CONVOCAMOS a un acto contra la impunidad a genocidas. Resumen Latinoamericano. Disponível em: < http:/ / www.resumenlatinoamericano.org/2017/05/04/ argentina-repercusiones-ante-fallo-de-la-corte-suprema-organismos-de-derechos-humanos-convocanacto-contra-la-impunidad-a-genocidas-que-nos-devuelvan-la-mitad-del-dolor-a-donde-vayan-los-volv $/>$. Acesso em: 20 jun. 2017.

ROHT-ARRIAZA, Naomi. State Responsibility to Investigate and Prosecute Grave Human Rights Violations in International Law. California Law Review, n. 78, p. 449-513, 1990.

SIEGEL, Reva B. Constitutional Culture, Social Movement Conflict and Constitutional Change: the case of the De Facto Era. 2005-06. California Law Review, 2006.

STEPHANOPOULOS, Nicholas. The Case for the Legislative Override. UCL A Journal of International Law and Foreign Affairs 250, p. 251-295, 2005.

TORELLY, Marcelo D. A formação da norma global de responsabilidade individual: mobilização política transnacional, desenvolvimento principiológico e estruturação em regras internacionais e domésticas. In: MEYER, Emilio Peluso Neder; OLIVEIRA, Cattoni de (Orgs.). Justiça de transição nos 25 anos da Constituição de 1988. 2. ed. Belo Horizonte: Initia Via, 2014. 
Para publicar na Revista de Direito Internacional, acesse o endereço eletrônico www.rdi.uniceub.br ou www.brazilianjournal.org.

Observe as normas de publicação, para facilitar e agilizar o trabalho de edição. 